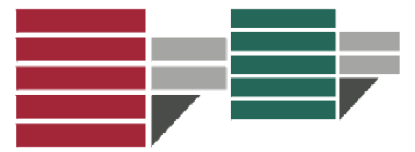

Working Paper n. 14 - 2010

\title{
SOCIAL COMPARISON AND SUBJECTIVE WELL-BEING: \\ DOES THE HEALTH OF OTHERS MATTER?
}

\author{
Vincenzo Carrieri \\ Dipartimento di Economia and Statistica \\ Università della Calabria \\ Ponte Pietro Bucci, Cubo 0/C \\ Tel.: +390984 492433 \\ Fax: +390984 492421 \\ e-mail: carrieri@unical.it
}

\section{Luglio 2010}

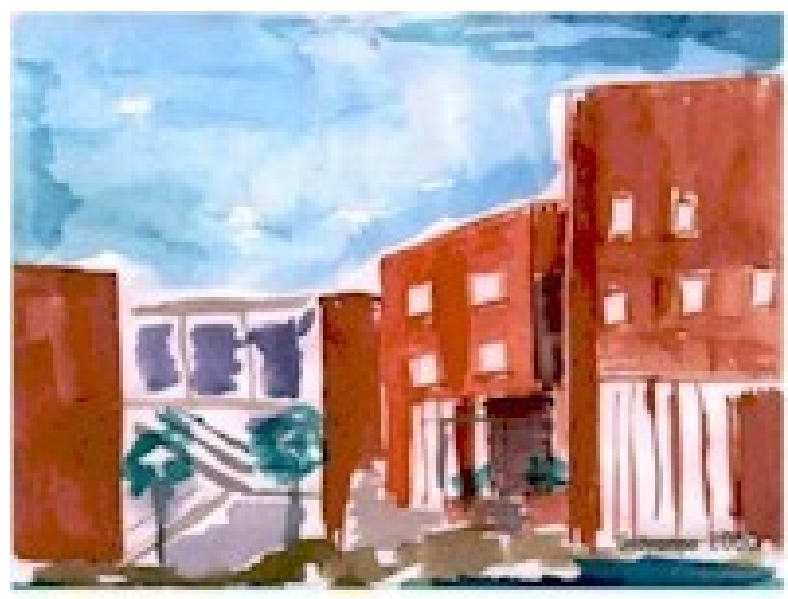




\title{
Social comparison and subjective well-being:
}

Does the health of others matter? ${ }^{(\dagger)}$

\author{
Vincenzo Carrieri ${ }^{(*)}$ \\ Department of Economics and Statistics \\ University of Calabria
}

\begin{abstract}
The importance of social comparison in shaping individual utility has been widely documented by subjective well-being literature. So far, income has been the main dimension considered in social comparison. This paper aims to investigate whether subjective well-being is influenced by inter-personal comparison with respect to health. Thus, we study the effects of the health of others and relative health hypothesis on two measures of subjective wellbeing: happiness and subjective health. Using data from the Italian Health Conditions survey, we show that a high incidence of chronic conditions and disability among reference groups negatively affects both happiness and subjective health. Such effects are stronger among people in the same conditions. These results, robust to different econometric specifications and estimation techniques, suggest the presence of some sympathy in individual preferences with respect to health and reveal that other people's health status serves as a benchmark to assess one's own health conditions.
\end{abstract}

JEL classification: C21; D64; I31

Keywords: health conditions; social comparison; subjective well-being.

$(\dagger)$ I wish to thank Maria De Paola for her comments, ideas and suggestions on a preliminary version of this paper. Thanks are also due to Elena Granaglia, Leandro Elia and Paolo Trevisan for their comments. The usual disclaimers apply.

(*)Address: Department of Economics and Statistics, Ponte Bucci, Cubo 0/C, University of Calabria, 87036 Arcavacata di rende (CS). Tel (39) 0984-492433. E-mail: carrieri@unical.it 


\section{INTRODUCTION}

Investigating the determinants of individual well-being is becoming a popular task among empirical economists. Research on this topic has become even more popular in recent years, thanks to the availability of surveys on self-rated happiness and life satisfaction for many countries.

However, measuring utility poses a number of relevant problems. Some scholars have showed that self-rated happiness scores are not completely reliable, as they can be influenced by contingent circumstances and recall bias due to the temporal sequence of relevant events. Others argue that happiness scores are subject to important cultural biases among countries (Ostroot and Snyder, 1985) ${ }^{1}$. Despite these difficulties, research on subjective well-being is important for many reasons, especially on normative grounds. Measuring happiness permits, for instance, the evaluation of the welfare net effects of policies which imply some kind of trade-off (ie inflation vs unemployment) (Frey and Stutzer, 2002); it allows the estimation of the effects on utility of institutional aspects, such as public governance (Helliwell 2003) or the estimation of the value that people assign to non-marketable goods, such as health or environment (Ferrer-i-Carbonell and van Praag, 2002; Clark and Oswald, 2002; De Mello and Tiongson, 2009). In addition, investigating the determinants of subjective well-being can help "to shed new light on basic concepts and assumptions of economic theory" (Frey and Stutzer, 2002, p. 403).

Leaving aside many important contributions by other research communities (mainly philosophers, psychologist and sociologist) the main interest of economists on this topic has been the investigation of the role of income on happiness. Standard neo-classical theory suggests, in fact, that income positively affects utility, allowing individuals to buy consumption and investment goods. The empirical research has provided support to this assumption showing that income plays a crucial role in defining individual well-being.

More recently, with the intention to interpret the well-known Easterlin paradox (1974), wellbeing literature has shown that relative income, more than absolute income, drives happiness. People get utility not only by objective conditions (i.e. higher income) but also by social comparison. In other words, it is not income per se that matters for utility but rather the position a person has in society.

In the same period, similar conclusions have been reached by other research communities (mainly epidemiologists and sociologists) focused on understanding health inequalities among

\footnotetext{
${ }^{1}$ We recall just a few of the methodological criticisms on happiness scores. A detailed elaboration of this critique is presented in Kahneman et al. (1999).
} 
different social groups. This research stream has highlighted that relative income contributes to the enhancement of both subjective and objective health conditions by reducing health-damaging factors such as stress and social isolation and by increasing health-promoting factors such as a good diet and physical exercise.

In summary, these two research streams suggest that inter-personal comparison strongly influences the subjective assessment of happiness and health, but so far, income has been the only dimension considered in social comparison.

This paper analyses the role of interpersonal comparison with respect to health on happiness and subjective health using data from the Italian Health Conditions survey 2004-2005 (Condizioni di salute e ricorso ai servizi sanitari). Our approach follows the idea that happiness and health present a lot of structural analogies, being two related dimensions of human well-being. Unlike most literature focused on the influence of income in social comparison, we consider the role of health as a dimension of social comparison. A social comparison with respect to health is to be expected being that health is the main determinant of individual well-being, probably much more than income (Ferrer-i-Carbonell and van Praag, 2002; Clark and Oswald, 2002; De Mello and Tiongson ,2009; Frey and Stutzer, 2002). Furthermore, some interest in the health of others may rely on two grounds. First, individuals might care about others' health status, because of altruism or sympathy ${ }^{2}$. Second, other's health status may matter for individuals as a benchmark to assess their own health conditions. This hypothesis is part of the debate around the reliability of subjective health as a proxy of objective health (see Sen, 2002 or Bago d'Uva et al. 2008, for a discussion)

Controlling for various conventional determinants of subjective well-being and using a standard reference group identification criteria, we find that a high incidence of chronic and disability conditions in the reference group affects negatively both happiness and subjective health and that this effect is stronger among people with similar health conditions. These results are robust to different econometric specifications and estimation techniques. In addition, despite some peculiarities, our results are valid even across people with a likely different cultural background (living in the North $v s$ the South of the country).

\footnotetext{
${ }^{2}$ The difference between these two concepts relies on the validity of the hypothesis of selfish individuals. According to Sen's sympathy concept (1977), the presence of some interest on the well-being of others could be explained even without relaxing the hypothesis of self-interested individuals. As Sen (op cit. p. 95) states "behaviour based on sympathy is in an important sense egoistic for one is one-self pleased at others' pleasure and pained at others' pain and the pursuit of one's own utility may thus be helped by sympathetic action". Sympathy can be viewed, then in terms of externalities. The importance of this concept in health care has been highlighted by Culyer (1976).
} 
The rest of the paper is organized as follows. Section two briefly summarizes literature on the importance of social comparison for subjective well-being. Section three presents the data. Section four sketches out the empirical model and describes the variables used in the analysis, along with some descriptive statistics. Section five presents and discusses the results along with some robustness checks. The last section summarizes and concludes.

\section{SOCIAL COMPARISON AND SUBJECTIVE WELL-BEING}

After the Easterlin (1974) seminal paper, subjective-well being research has been deeply concerned about the influence of social comparison in shaping individual utility. By showing the flat level of happiness in the last 100 years even in the presence of a strong increase in absolute income, Easterlin's paper (1974) has been a cornerstone for happiness research for two reasons. On the one hand, it suggests that income plays a minor role in happiness once an individual rises above a poverty line or 'subsistence level', while on the other hand, it implies that happiness depends strongly on relative status.

To put it formally, what seems to matter for happiness is individual income compared to the income of a "reference group":

$$
\frac{y_{i t}}{y_{t}^{*}}
$$

where $y_{i t}$ is individual income at time $t$ and $y_{t}^{*}$ is the income of individual $i$ 's "reference group" at time $t$. Theoretical literature has suggested two definitions of reference income group, both internal (past individual income) and external (where comparisons refer to distinct demographic groups such as one's own family, other workers at the individual's place of employment, people in the same neighbourhood, region, country, or even people across a whole set of countries). Both definitions have lead to the same result, namely, that income cannot buy happiness per se, but relative income can (Clark et al., 2007; Heady, 1991; Diener, et. al., 1993; Frey and Stutzer, 2000; Easterlin, 2001; Van Praag and Ferrer-i-Carbonell, 2004).

Many scholars from various research communities (mainly epidemiologists and sociologists) investigating the social determinants of health have reached similar conclusions, that is, social comparison does matter. The bulk of literature found that, in richer countries, relative income is the first predictor of health (both subjective and objective), even greater than any other individual risk factor (Marmot and Wilkinson, 2006). People in lower relative status, in fact, are likely to be exposed to behavioural risks (such as smoking, low exercise, diet) and to psychosocial risks such as stress and social isolation that are health damaging, both on mental and physical grounds 
(Kakwachi et al, 1997, Kakwachi and Kennedy, 1997, Wilkinson, 1996; Hsieh e Pugh, 1993). Such factors also accumulate together, showing a high intergenerational persistence (Power et al. 1998).

Therefore, happiness and subjective health research seems to support the idea that social comparison is a key factor for subjective well-being. So far, income has been the main dimension considered. In this work we argue that this view is too restrictive because inter-personal comparison is likely to be performed even with respect to other dimensions of well-being. Health status is probably one of these for three reasons.

Firstly, health is the most important determinant of individual well-being. Clark and Oswald (2002), for instance, show that the largest valuation in happiness comes from health status, and an individual whose "health declines from excellent to good would require a payment of tens of thousands of pounds per month in order for the happiness score to remain unchanged'". Frey and Stutzer (2002, p.56) remark that "when people are asked to evaluate the importance of various areas of their lives, good health obtains the higher rating". Ferrer-i-Carbonell and van Praag, (2002) and De Mello and Tiogson (2009) reach similar results. In addition, health conditions strongly correlate with other dimensions of well-being such as job satisfaction (Sales and House, 1971; Wall et al., 1978).

Secondly, one might be interested in the health of others both on altruism and sympathy grounds. People might care about the health of others because they are not selfish or because staying with people in good health increases their individual utility. As Culyer (1976) suggests, others' illness influences well-being, not only because of the risk to be infected, but because most people care.

Finally, other's health status might serve as a benchmark to assess one's own health conditions. Indeed, self-assessment of health status is influenced by the expectations for one's own health, that is likely to be based on the health conditions of some reference group. This idea is also part of the debate around the reliability of subjective health as a proxy of objective health (see Sen, 2002 or Bago d'Uva et al., 2008 for a discussion).

Hence, we believe that the role of health as a dimension of social comparison should be further investigated. Such analysis is generally absent in subjective well-being literature and even studies on altruism and happiness lack an explicit health dimension (see Schwarze and Winkelmann, 2005, for a discussion). ${ }^{3}$ This paper will try to fill this gap by exploring how health conditions of other people affect individual happiness and subjective health.

\footnotetext{
${ }^{3}$ De Mello and Tiongson (2009) are a noteworthy exception given that they explore the effect of family's health on individual happiness suggesting the presence of altruism in individual preferences. They don't consider, anyway, relative health effects and they do explore family's health rather than health of a reference group. This casts some doubts about the fact that a positive sign of family's health coefficient on happiness can be interpreted only on altruism
} 


\section{DATA}

We use data from the last wave (2004/2005) of the Italian Health Conditions survey (ISTATCondizioni di Salute e Ricorso ai Servizi Sanitari). The survey is conducted every 5 years on a nationally representative sample of 128,040 individuals and 50,474 households. Happiness scores are collected only for people aged more than 13 years old, then the analysis is carried out on a sample of 111,151 and 128,040 individuals for happiness and subjective health, respectively. The survey gathers information on health conditions, disabilities, life-styles, prevention and health-care use as well as information on individual and household socioeconomic conditions. Furthermore, despite the survey lack of a longitudinal dimension, it contains information on happiness and objective and subjective health, which renders this data-set particularly suitable to our research focus ${ }^{4}$.

\section{IV.EMPIRICAL MODEL AND VARIABLES DESCRIPTION}

We estimate the following empirical model of subjective well-being $(S W)$ :

$$
S W=\gamma H_{i t}+\delta \frac{H_{i t}}{H_{t}^{*}}+\theta Z
$$

Where $H_{i t}$ is individual health at time $t, \frac{H_{\text {it }}}{H_{t}^{*}}$ is individual health compared to the health of reference group $\left(H_{t}^{*}\right)$ at time $t$ and $Z$ is a vector of other explanatory variables. We estimate (2) using two measures of subjective well-being: subjective health and happiness.

Subjective health is measured according to the standard question: "How do you rate your health?" with five conventional answers "Very Good, Good, Fair, Bad, Very Bad”. Happiness is measured according to the following question and answer on a six-point scale : "All together, how many times did you feel happy in the last four weeks? Always, Almost Always, Many times, Sometimes, Almost Never, Never".

We have information on 24 chronic conditions and several disability conditions grouped in 4 areas (Blindness and visual impairments, Deaf Mutism, mobility or orthopedic impairments, mental illness or emotional disturbance). All these conditions are self-reported but diagnosed by a physician; this should ensure that we refer to objective health conditions. Individual health is 
measured, then, through a dummy variable equal to one if an individual suffers from one or more chronic or disability conditions and zero otherwise. We use two measures to define Health of others. First, along with De Mello and Tiongson (2009), we refer to family health. One question in the data-set explicitly asks if one household member had suffered or suffers from a severe illness; we build a dummy equal to one in this case and equal to zero otherwise. As a second measure of the Health of others, we use the proportion of persons that suffer from chronic and disability conditions among the individual reference group. Reference group of individual $i$ is identified by the people who are 5 years older or younger than $i$, living in the same region, having attained a similar level of education (one degree above or below ISCED category than individual $i$ ), are in the same socioprofessional status (unemployed, retired, etc.) and live in the same area (rural/urban). This reference group identification is quite common in happiness literature (see Ferrer-I-Carbonell, 2005 and Mcbride, 2001). The living area variable is probably less common, but we prefer to use it given that generally health profiles are very different among people living in rural and urban areas. Then, the effect of Relative health is measured by the interaction between individual health and the proportion of people suffering from chronic diseases or disabilities in the reference group.

Vector $Z$ contains the following variables: individual socio-professional status (unemployed, employed, housekeeper, unable to work, retired, other categories), housing conditions (problems with light, humidity, heating), living area (urban/rural), marital status (single, married, divorced, separated, widow), sex, education (5 ISCED levels), a polynomial specification of age and some measures of relational goods and social capital (namely, the feeling of presence/no presence of relatives, friends, neighbours and volunteer organization in case of any personal need). It is noteworthy to observe that the variables used to identify the reference group of individual $i$ (age, education, socio-professional status and living area) are all included in the regressors set. This should ensure that the coefficient $\delta$ in equation (2) is not contaminated by the variables chosen to identify the groups.

Unfortunately the data-set we use does not contain information on income but it provides information with self-evaluation of family economic resources on a four point scale: optimum circumstances, fair, insufficient, absolutely insufficient. We use four dummies to measure it.

In the subjective health equation we also add some variables of health care use, such as having had a medical visit in the last four weeks and the days of hospitalization in the last three months. The underlying hypothesis is that health care consumption can increase health status but it does not generate utility per se. Summary statistics and a description of all variables are presented in Table 1A (Appendix). In the case of qualitative variables, the first category presented is always the one chosen as a reference in the model. 
We estimate equation (2) using both an OLS and ordered probit estimator. Both regressions are run correcting covariance-matrix for intra-reference group correlation, in order to avoid the socalled "Moulton problem" (Moulton, 1986). In section 4.1 and 4.2 some other empirical specifications are used, in order to check the robustness of our results.

\section{RESULTS}

Estimates of equation (2) for happiness and subjective health are presented in Table 2and table 2A (Appendix) ${ }^{5}$. Qualitatively, OLS and ordered probit estimations lead to similar results both with respect to signs and statistical significance.

Before discussing the main variable of interest, we briefly have a look at the other explanatory variables. The results we found are pretty standard in the empirical literature of subjective wellbeing, but what is interesting is that happiness and subjective health seems to depend on very similar factors. Indeed, we find that objective health, economic circumstances, education, employment status, social capital and housing conditions are positive determinants of both happiness and subjective health. A positive effect of education on happiness has been found also by Easterlin (2005) while with respect to subjective health, our results are coherent with Furnèe et al. (2008). The effect of employment on happiness is in line with other papers (Clark and Oswald, 1994; Darity and Goldsmith, 1996; Frey and Stutzer, 2002). Concerning relational goods, a positive effect on happiness has been found by Bruni and Stanca (2008), while a positive role of relational goods and social capital on health has been found by Joshi et al. (2000), Kakwachi et al. (1997), Kakwachi and Kennedy (1997), Wilkinson (1996). Regarding studies on Italian data, the effects of economic circumstances, education, employment status and social capital on happiness that we found are coherent with Scoppa and Ponzo (2008). Finally, we find that happiness and subjective health are higher among males and have a non-linear relation with respect to age (the non linear relation between happiness and age has been found also by Blanchflower and Oswald, 2007). As a non-standard result, we find that subjective well-being is negatively influenced by housing problems. The relation between housing problems and health is well-documented in literature (see Joshi et al., 2000), while the effect on happiness is novel. Once again, this finding supports the idea that happiness and subjective health determinants are strongly comparable.

\footnotetext{
${ }^{5}$ We show the results based on 104,342 and 109,129 individuals for happiness and subjective health analysis, respectively. The figures are slightly different to the ones shown in section 2, because we retain only the reference groups comprised of at least 10 individuals. We end-up, then, with 464 reference groups with an average of 269 peers for each group. This choice relies on the belief that a reference group with very few individuals turns out to be inappropriate for the social comparison process we have in mind. Anyway, we did not notice any important difference when estimating the model including all the reference groups.
} 
With respect to the key variable of our paper, we find (Table 2) that health strongly matters for social comparison. We find that as the health of the reference group decreases (a higher proportion of chronic and disabled individuals) both happiness and subjective health decreases. The same occurs with respect to the health of family members which is also a positive determinant of both happiness and subjective health. This last result is in line with De Mello and Tiongson (2009) while, to the best of our knowledge, there are no previous papers that have investigated the relation between the health of the reference group and subjective well-being. Furthermore, we find that the effect of the health of the reference group is stronger among people in bad health conditions. This result occurs both with respect to happiness and subjective health. It seems, then, that both benchmark and sympathy hypotheses are confirmed. People seem to use others' health status as a benchmark to assess one's own health conditions and because they care about others' health status. In particular, the sympathy hypothesis seems to hold with respect to happiness results given that people in bad health may have more consideration towards persons with similar conditions.

Table 2. Estimates results (Main covariates)- Health of reference group and relative health hypothesis

\begin{tabular}{|c|c|c|c|c|}
\hline Main Covariates & $\begin{array}{c}\text { (1) } \\
\text { Happiness } \\
\text { OLS }\end{array}$ & $\begin{array}{c}\text { (2) } \\
\text { Happiness } \\
\text { Ordered Probit }\end{array}$ & $\begin{array}{c}\text { (3) } \\
\text { Subjective health } \\
\text { OLS }\end{array}$ & $\begin{array}{c}\text { (4) } \\
\text { Subjective health } \\
\text { Ordered Probit }\end{array}$ \\
\hline $\begin{array}{l}\text { Proportion of sick } \\
\text { in the reference group }\end{array}$ & $\begin{array}{c}-0.359 * * * \\
(-4.96)\end{array}$ & $\begin{array}{c}-0.362 * * * \\
(-5.39)\end{array}$ & $\begin{array}{c}-0.293 * * * \\
(-6.93)\end{array}$ & $\begin{array}{c}-0.573 * * * \\
(-7.62)\end{array}$ \\
\hline $\begin{array}{l}\text { Sick*proportion of sick } \\
\text { in the reference group }\end{array}$ & $\begin{array}{c}-0.255^{* * * *} \\
(-5.63)\end{array}$ & $\begin{array}{c}-0.176^{* * * *} \\
(-4.20)\end{array}$ & $\begin{array}{c}-0.251 * * * \\
(-10.09)\end{array}$ & $\begin{array}{c}-0.320 * * * \\
(-7.30)\end{array}$ \\
\hline $\mathrm{N}$ & 104342 & 104342 & 109129 & 109129 \\
\hline Asjusted $\mathrm{R}^{2}$ & 0.167 & & 0.431 & \\
\hline Log-Likelihood & -164372.1 & -153523.0 & -108502.7 & -106223.2 \\
\hline Chi-Square Stat. & & 13011.2 & & 30249.1 \\
\hline
\end{tabular}

t- statistics in parentheses. Standard errors are clustered on 464 reference groups $* p<.10, * * p<.05, * * * p<0.01$ 


\section{Robustness Check}

In this section, we deal with one issue that might weaken the casual relationship we found between the health of the reference group and subjective well-being. Indeed, it can be argued that this relationship might arise because we do not consider the effect of the income of the reference group in our regressions. Empirical evidence, in fact, shows that people in better economic circumstances are even in better health (see Van Doorslaer and Koolman 2004, among others). An effect of the income of the reference group on subjective well-being, then, could bias the coefficient $\delta$ of equation (2).

To work-out such troubles, we re-run equation (2), adding as covariates, a measure of the proportion of people reporting to be in optimum economic circumstances in the reference group. Estimate results of such estimates are presented in Table 3 (All covariates are presented in Table 3A in appendix).

In these new estimates, both the coefficients of health of the reference group and relative health are still significant at $1 \%$. In OLS estimates the effect is smaller in magnitude. This means that a small part of the effect of the reference group's health is due to an income effect, but health per se has a very significant effect on subjective well-being.

As for the income of the reference group, we find a slightly significant effect only on subjective health (10\% of significance). In any case, we would advise not to rely too strongly on this coefficient, since a subjective evaluation of economic circumstances and endogeneity problems may lead to biased estimates. For our concerns, what is important is that controlling for the income of the reference group does not change our main results. 
Table 3. Robustness check (Main Covariates)

\begin{tabular}{|c|c|c|c|c|}
\hline \multirow[t]{3}{*}{ Main Covariates } & (1) & (2) & (3) & (4) \\
\hline & Happiness & Happiness & Subjective health & Subjective health \\
\hline & OLS & Ordered Probit & OLS & Ordered Probit \\
\hline \multirow{2}{*}{$\begin{array}{l}\text { Proportion of rich } \\
\text { in the reference group }\end{array}$} & 0.117 & 0.146 & $-0.162^{*}$ & $-0.267^{*}$ \\
\hline & $(0.58)$ & $(0.82)$ & $(-1.72)$ & $(-1.66)$ \\
\hline \multirow{2}{*}{$\begin{array}{l}\text { Proportion of sick } \\
\text { in the reference group }\end{array}$} & $-0.354 * * *$ & $-0.356 * * *$ & $-0.299 * * *$ & $-0.584 * * *$ \\
\hline & $(-4.88)$ & $(-5.28)$ & $(-7.03)$ & $(-7.71)$ \\
\hline \multirow{2}{*}{$\begin{array}{l}\text { Sick*proportion of sick } \\
\text { in the reference group }\end{array}$} & $-0.254 * * *$ & $-0.175 * * *$ & $-0.251 * * *$ & $-0.320 * * *$ \\
\hline & $(-5.62)$ & $(-4.18)$ & $(-10.11)$ & $(-7.32)$ \\
\hline $\mathrm{N}$ & 104342 & 104342 & 109129 & 109129 \\
\hline Asjusted $\mathrm{R}^{2}$ & 0.167 & & 0.432 & \\
\hline Log-Likelihood & -164371.8 & -153522.5 & -108500.9 & -106221.5 \\
\hline Chi-Square Stat. & & 13039.6 & & 30091.6 \\
\hline
\end{tabular}

$\mathrm{t}$ - statistics in parentheses. Standard errors are clustered on 464 reference groups $* p<.10, * * p<.05, * * * p<0.01$

\section{Robustness to cultural differences}

As a further robustness check, we try to deal with a potential cultural effect that may systematically change the determinants of subjective well-being across people with different cultural backgrounds. Indeed, one important criticism to the use of happiness scores for the assessment of human wellbeing determinants relies on the possible presence of a cultural bias among countries (Ostroot and Snyder,1985). Such cultural bias could depend on language differences, the familiarity with concepts such as 'happiness' and 'satisfaction' and the social desirability of the responses. This fact is strongly related to values and attitudes of people living in the same community which may systematically affect the perception of what a happy life means. Ostroot and Snyder (1985) demonstrate that cultural differences can deeply affect cross-country comparison of happiness scores, contributing to the explanation of $40 \%$ of the differences in life satisfaction between the French and the Americans, for instance. 
Even for subjective health assessment, cultural aspects may be relevant. Let's think for example about religious aspects that can affect the decision to undergo medical treatment (such as the prohibition to accept blood donation for some religious groups) or "non conventional" treatments that some indigenous groups receive when ill. To a greater extent, some have argued that health itself is a cultural construct rather than just the physical well-being of the individual; in which case it should be viewed as the emotional, social and cultural well-being of the whole community (Mooney, 2009).

Our data, based on the Italian population, is evidently not suitable for cross-country comparison, but can serve to check the validity of our results across people with different cultural backgrounds. In fact, Italy presents relevant cultural differences between the North and the South part of the country. The North part of the country is very developed with, on average, high levels of education and it is geographically very closed to the heart of Europe. This contributes to the shaping of a Western-European cultural background. On the other side, the South part of the country is quite poor, less educated and geographically close to north-African and other Mediterranean countries. People from the south are then more linked to a Mediterranean cultural background.

Hence, we run separate regressions for people living in the North and the South of the country to see whether cultural differences affect the role of health as a dimension of social comparison. In these regressions we control also for the income of the reference group. Estimation results are shown in Tables 4 and 5 (all covariates are shown in Table 4A and Table 5A in the Appendix). As it can be noted, it seems that the main results of our paper remain confirmed, but with some particularities. We find that people in the South are more influenced by social comparison with respect to health when assessing their subjective health conditions, while they do not care in a significant way about the health of others in terms of individual utility. On the other side, it seems that the reverse occurs in the North, where people seem to care about the health of others for individual utility, but not to assess their own health. Anyway, in all regressions, both for happiness and subjective health, people in poor health are significantly affected by the health of the reference group. Hence, it seems that people from a Western-European cultural background perform social comparison regardless of their own individual health conditions, while subjective well-being of people from a Mediterranean cultural background is influenced only by the health of people in similar conditions. Even with these differences, some interest in the health of others is present for people both from a Mediterranean and Western-European cultural background. 
Social Comparison And Subjective Well-being

Table 4. Estimates results. People living in the South of Italy

\begin{tabular}{|c|c|c|c|c|}
\hline Main Covariates & $\begin{array}{c}\text { (1) } \\
\text { Happiness } \\
\text { OLS }\end{array}$ & $\begin{array}{c}\text { (2) } \\
\text { Happiness } \\
\text { Ordered Probit }\end{array}$ & $\begin{array}{c}\text { (3) } \\
\text { Subjective health } \\
\text { OLS }\end{array}$ & $\begin{array}{c}\text { (4) } \\
\text { Subjective health } \\
\text { Ordered Probit }\end{array}$ \\
\hline $\begin{array}{l}\text { Proportion of rich } \\
\text { in the reference group }\end{array}$ & $\begin{array}{l}-0.219 \\
(-0.84)\end{array}$ & $\begin{array}{l}-0.166 \\
(-0.71)\end{array}$ & $\begin{array}{c}-0.474 * * * \\
(-3.77)\end{array}$ & $\begin{array}{c}-0.790 * * * \\
(-3.69)\end{array}$ \\
\hline $\begin{array}{l}\text { Proportion of sick } \\
\text { in the reference group }\end{array}$ & $\begin{array}{l}0.125 \\
(1.15)\end{array}$ & $\begin{array}{r}0.0801 \\
(0.80)\end{array}$ & $\begin{array}{c}-0.364 * * * \\
(-6.08)\end{array}$ & $\begin{array}{c}-0.680 * * * \\
(-6.59)\end{array}$ \\
\hline $\begin{array}{l}\text { Sick*proportion of sick } \\
\text { in the reference group }\end{array}$ & $\begin{array}{c}-0.260 * * * \\
(-3.90)\end{array}$ & $\begin{array}{c}-0.182 * * * \\
(-3.02)\end{array}$ & $\begin{array}{c}-0.280 * * * \\
(-7.35)\end{array}$ & $\begin{array}{c}-0.353 * * * \\
(-5.57)\end{array}$ \\
\hline $\mathrm{N}$ & 42223 & 42223 & 44470 & 44470 \\
\hline Asjusted $\mathrm{R}^{2}$ & 0.201 & & 0.484 & \\
\hline Log-Likelihood & -65903.7 & -61285.3 & -44340.1 & -43028.6 \\
\hline Chi-Square Stat. & & 7524.7 & & 19801.2 \\
\hline
\end{tabular}

t- statistics in parentheses. Standard errors are clustered on 464 reference groups . $* p<.10, * * p<.05, * * * p<0.01$ 
Table 5. Estimates results. People living in the North-Centre of Italy

\begin{tabular}{|c|c|c|c|c|}
\hline Main Covariates & $\begin{array}{c}\text { (1) } \\
\text { Happiness } \\
\text { OLS }\end{array}$ & $\begin{array}{c}\text { (2) } \\
\text { Happiness } \\
\text { Ordered Probit }\end{array}$ & $\begin{array}{c}\text { (3) } \\
\text { Subjective health } \\
\text { OLS }\end{array}$ & $\begin{array}{c}\text { (4) } \\
\text { Subjective health } \\
\text { Ordered Probit }\end{array}$ \\
\hline $\begin{array}{l}\text { Proportion of rich } \\
\text { in the reference group }\end{array}$ & $\begin{array}{l}0.343 \\
(1.22)\end{array}$ & $\begin{array}{l}0.349 \\
(1.42)\end{array}$ & $\begin{array}{l}0.206 \\
(1.55)\end{array}$ & $\begin{array}{l}0.327 \\
(1.42)\end{array}$ \\
\hline $\begin{array}{l}\text { Proportion of sick } \\
\text { in the reference group }\end{array}$ & $\begin{array}{c}-0.405 * * * \\
(-3.76)\end{array}$ & $\begin{array}{c}-0.383 * * * \\
(-3.93)\end{array}$ & $\begin{array}{l}-0.0594 \\
(-1.02)\end{array}$ & $\begin{array}{l}-0.154 \\
(-1.51)\end{array}$ \\
\hline $\begin{array}{l}\text { Sick*proportion of sick } \\
\text { in the reference group }\end{array}$ & $\begin{array}{c}-0.401 * * * \\
(-5.83)\end{array}$ & $\begin{array}{c}-0.315 * * * \\
(-5.01)\end{array}$ & $\begin{array}{c}-0.388 * * * \\
(-12.55)\end{array}$ & $\begin{array}{c}-0.588 * * * \\
(-10.66)\end{array}$ \\
\hline $\mathrm{N}$ & 62119 & 62119 & 64659 & 64659 \\
\hline Asjusted $\mathrm{R}^{2}$ & 0.145 & & 0.392 & \\
\hline Log-Likelihood & -98306.6 & -92063.9 & -63787.5 & -62790.3 \\
\hline Chi-Square Stat. & & 7071.9 & & 20116.4 \\
\hline
\end{tabular}

t- statistics in parentheses. Standard errors are clustered on 464 reference groups. $* p<.10,{ }^{* *} p<.05, * * * p<0.01$

\section{FINAL REMARKS}

This paper analyses the role of social comparison on happiness and self-assessed health using data from the Italian Health Conditions survey (Condizioni di salute e ricorso ai servizi sanitari). We test whether individuals are influenced by the health of their reference group in their self-evaluation of happiness and subjective health. Our investigation might present two aspects of interest with respect to previous literature on subjective well-being. First, we investigate the role of health as a potential term of social comparison. Empirical literature on subjective well-being, in fact, has focused mainly on income as a term of comparison between individuals. In this paper, we have argued that an inter-personal comparison with respect to health is to be expected, given its relevance for human well-being and because it could be indicative of some sympathy in individual preferences or it could serve as a benchmark to assess one's own health conditions. Second, we test the impact of the health of the reference group on happiness and subjective health, considering them as two related dimensions of well-being. 
We perform our analysis checking for other conventional determinants of subjective well being, such as health, income, education, occupational status and social capital while using a generally accepted measure of reference group identification (see Ferrer-I-Carbonell (2005) and Mcbride (2001)). To check the robustness of our results, we even test for the effect of income of the reference group. In addition, we perform the analysis on two separate samples of people living in the North and the South of Italy, in order to check the stability of our results across people with different cultural backgrounds.

The main result of the paper is that the health of the reference group does positively influence subjective well-being. We find that a high incidence of chronic and disability conditions among a reference group negatively affects both happiness and subjective health. This result seems to show that individual preferences, with respect to health, elicit some altruism or sympathy and demonstrate that people are influenced by other's health in assessing their own health conditions. Regarding relative health, we found that people with bad health conditions are more negatively influenced by the bad health of others than people in good health. This last result seems to support the sympathy hypothesis given that people in bad health may have more consideration towards persons with similar conditions.

As a secondary result, we found that underlying casual mechanisms of happiness and health are somehow alike. Individual health, economic circumstances, education, employment status and social capital are positive determinants of both the happiness and subjective health. Furthermore, we found that housing problems are both health-damaging and happiness-reducing.

On a normative ground, our results might be consistent with Culyer's old argument (1976) which supports the public financing of health care, ie. the institution of national health service. Culyer's ideas rely on the presence of positive externalities with respect to health, namely, that people might care for others' health. This hypothesis, confirmed here, is obvious with respect to contagious diseases but perhaps it is interesting for non-contagious illness, such as the ones we considered in this paper.

With regards to further research, it could be interesting to investigate the role of other dimensions of social comparison in subjective well-being. Our paper has shown that health is important, but other determinants could be at work. Furthermore, even if we try to check the stability of our results across people with different cultural backgrounds, we have conducted the research only on an Italian population. An empirical investigation across countries would be useful to gain new insights on other dimensions of social comparison that influence subjective well-being. 


\section{REFERENCES}

1. Bago D’Uva, T. et al. (2008) Does reporting heterogeneity bias the measurement of the health disparities? Health Economics, vol. 17(3), pages 351-375.

2. Blanchflower, D.G., Oswald, A.J. (2007) Is Well-being U-Shaped over the Life Cycle? Warwick Economic Research Papers, No 826, Department of Economics, University of Warwick.

3. Bruni, L., \& Stanca, L. (2008). Watching Alone: Relational Goods, Television and Happiness. Journal of Economic Behavior and Organization, 65(3-4), 506-528.

4. Clark, A.E., and A.J., Oswald, (1994), Unhappiness and Unemployment, Economic Journal, vol.104. pp.648-659.

5. Clark, A E., Oswald A.J. (2002). A Simple Statistical Method for Measuring How Life Events Affect Happiness, International Journal of Epidemiology, Vol. 31: pp. 1139-44.

6. Clark, A.E., Frijters, P., Shields, M. (2007), Relative Income, Happiness and Utility: An Explanation for the Easterlin Paradox and Other Puzzles, IZA DP No. 2840, June 2007.

7. Culyer A.J. (1976) Need and the national service. Martin Robertson, Oxford.

8. Darity, W., and A.H. Goldsmith, (1996), Social Psychology, Unemployment and Macroeconomics, Journal of Economic Perspectives, 10 (1), 121-40.

9. De Mello, L., Tiongson, E.R. (2009) What Is the Value of (My and My Family's) Good Health?, Kyklos, Vol. 62 , No. 4,pp. 594-610.

10. Diener, E., Sandvik, E., Seidlitz, L., \& Diener, M. (1993). The relationship between income and subjective wellbeing: Relative or absolute? Social Indicators Research, 28, 195-223

11. Easterlin, R. (1974). Does economic growth improve the human lot? Some empirical evidence. In P. A. David \& M. W. Reder (Eds), Nations and households in economic growth (pp.89-125). Academic Press. 
12. Easterlin, R. (2001). Income and happiness: Toward a unified theory. Economic Journal $111,464-84$

13. Easterlin, R.A. (2005), Building a Better Theory of Well-Being, in Bruni, L. and P.-L. Porta, Economics and Happiness. Framing the analysis, pp.29-64, Oxford University Press, Oxford.

14. Ferrer-i-Carbonell, A. van Praag, B.M.S ( 2002). The Subjective Costs of Health Losses due to Chronic Diseases: An Alternative Model for Monetary Appraisal, Health Economics. Vol. 11: pp. 709-22.

15. Ferrer-i-Carbonell, A. (2005). Income and well being: an empirical analysis of the comparison income effect. Journal of Public Economics, 89, 997-1019.

16. Frey, B., Stutzer, A. (2000). Happiness, economy and institutions. Economic Journal, 110, 918-938.

17. Frey, B., Stutzer, A. (2002). What Can Economists Learn from Happiness Research?, Journal of Economic Literature, Vol. 40: pp. 402-35.

18. Furnèe, C.A., Groot, W., Van Den Brink,H.M. (2008), The health effects of education: a meta-analysis, European Journal of Public Health, Vol. 18, No. 4, 417-421

19. Heady, B. (1991). An economic model of subjective well-being: Integrating economic and psychological theories. Social Indicators Research, 28, 97-116.

20. Helliwell, J.F. (2003) How's life? Combining individual and national variables to explain subjective well-being, Economic Modelling , 20 (2): 331-360.

21. Hsieh, CC., Pugh, M.D. (1993), Poverty, Income, inequality and violent crime: a metaanalysis of recent aggregate data studies. Crim. Justice Rev 18:182-202.

22. Joshi, H., Wiggins, E., Bartely, M.m Mitchell, R., Gleave, S., Lynch, K., (2000) Putting health inequalities on the map: does where you live matter, and why? In Graham, H., eds., Understanding health inequalities, Open University Press, pp. 143-155. 
23. Kahneman D, Diener E, Schwarz N (eds) (1999) Well-being: The Foundations of Hedonic Psychology. Russell Sage Foundation: New York.

24. Kawachi, B, Kennedy,P., Lochner, L., Prothrow-Stith, D. (1997), Social capital, income inequality, and mortality, American Journal of Public Health, Vol. 87, Issue 9 1491-1498

25. Kawachi, B., Kennedy, P. (1997), Socioeconomic determinants of health : Health and social cohesion: why care about income inequality? British Medical Journal ;314:1037.

26. Marmot, M e Wilkinson, R. (2006), Social Determinants of Health, 2nd Edition, Oxford: Oxford University Press.

27. McBride, M. (2001). Relative-income effects on subjective well-being in the cross-section. Journal of Economic Behavior and Organization, 45, 251-78.

28. Mooney, G. (2009), Is it not time for health economists to rethink equity and access, Health Economics, Policy and Law (2009), 4:209-221.

29. Moulton, B. (1986), Random Group Effects and the Precision of Regression Estimates, Journal of Econometrics, 32, 385.97.

30. Ostroot, N. M., Snyder, W. W.: 1985, 'Measuring cultural bias in a cross-national study', Social Indicators Research 17, pp. 243- 251.

31. Power, C., Matthews, S., Manor, O. (1998) Inequalities in self-rated health: explanations from different stages of life, Lancet, 351: 1009-14.

32. Sales, S.M. and J. House (1971). Job Dissatisfaction and a Possible Risk Factor in Coronary Heart Disease, Journal of Chronic Diseases. Vol. 23: pp. 861-73.

33. Schwarze, Johannes and RainerWinkelmann 2005. "What Can Happiness Research Tell Us About Altruism? Evidence from the German Socio-Economic Panel', IZA Discussion Papers No. 1487 (Bonn: Institute for the Study of Labor, IZA). 
34. Scoppa, V., Ponzo, M. (2008), An Empirical Study of Happiness in Italy, The B.E. Journal of Economic Analysis \& Policy, Vol. 8 : Iss. 1 (Contributions), Article 15.

35. Sen, A. (1977) Rational Fools: A critique of the behavioral foundation of economic theory, Philosophy and Public Affairs, 6 (4): 317-344.

36. Sen, A. (2002) Health: perception Vs Observation, British Medical Journal, 2002, 324: 860861.

37. Van Doorsaler, E., e Koolman, X.,(2004) Explaining the differences in income related health inequalities across European countries, Health Economics,13, pp. 609-628.

38. Van Praag, B.M.S. \& Ferrer-i-Carbonell, A. (2004), Happiness quantified: A satisfaction calculus approach. Oxford University Press.

39. Wall, T.D., C.W. Clegg and P.R. Jackson 1978. An Evaluation of the Job Characteristics Model, Journal of Occupational Psychology, Vol. 51: pp. 183-96.

40. Wilkinson, R.G. (1996), Unhealthy Societies: The Afflictions of inequality. New York: Routledge 


\section{APPENDIX}

Table 1A. Summary Statistics and Variable Description

\begin{tabular}{|c|c|c|c|c|}
\hline $\begin{array}{c}\text { Variable } \\
\text { Description }\end{array}$ & $\begin{array}{c}\text { Variable } \\
\text { Name }\end{array}$ & Mean & SD & $\begin{array}{l}\mathbf{N}^{\circ} \\
\text { Obs. }\end{array}$ \\
\hline \multicolumn{5}{|c|}{ Dependent Variables } \\
\hline $\begin{array}{l}\text { Self-rated } \\
\text { happiness }\end{array}$ & Happiness & 4.05 & 1.28 & 111,151 \\
\hline $\begin{array}{l}\text { Subjective } \\
\text { Health }\end{array}$ & $\begin{array}{c}\text { Subjective } \\
\text { health }\end{array}$ & 3.8 & 0.88 & 128,340 \\
\hline \multicolumn{5}{|c|}{ Covariates } \\
\hline \multirow[t]{2}{*}{ Gender } & Female & $51.65 \%$ & 0.49 & 128,040 \\
\hline & Male & $48.35 \%$ & 0.49 & 128,040 \\
\hline Age & Age & 47.58 & 19.35 & 128,040 \\
\hline \multirow{5}{*}{$\begin{array}{c}\text { Education } \\
\text { (Highest ISCED } \\
\text { level attained) }\end{array}$} & Illiterate & $9.95 \%$ & 0.3 & 121,145 \\
\hline & Primary & $23.81 \%$ & 0.42 & 121,145 \\
\hline & Junior & $30.30 \%$ & 0.46 & 121,145 \\
\hline & High & $27.90 \%$ & 0.45 & 121,145 \\
\hline & College & $8.04 \%$ & 0.27 & 121,145 \\
\hline \multirow[t]{4}{*}{$\begin{array}{c}\text { Self-assessed } \\
\text { Economic } \\
\text { Circumstances }\end{array}$} & $\begin{array}{l}\text { Absolutely } \\
\text { Insufficient }\end{array}$ & $4.50 \%$ & 0.2 & 128,040 \\
\hline & Insufficient & $26.46 \%$ & 0.44 & 128,040 \\
\hline & Fair & $65.39 \%$ & 0.47 & 128,040 \\
\hline & Optimum & $3.67 \%$ & 0.19 & 128,040 \\
\hline \multirow{6}{*}{$\begin{array}{l}\text { Professional } \\
\text { Status }\end{array}$} & Unemployed & $4.83 \%$ & 0.21 & 128,040 \\
\hline & Employed & $39.27 \%$ & 0.49 & 128,040 \\
\hline & Retired & $16.57 \%$ & 0.37 & 128,040 \\
\hline & other_occup & $2.00 \%$ & 0.14 & 128,040 \\
\hline & unable & $1.39 \%$ & 0.12 & 128,040 \\
\hline & housekeeper & $14.75 \%$ & 0.35 & 128,040 \\
\hline \multirow{2}{*}{$\begin{array}{c}\text { Individual } \\
\text { Health (one or } \\
\text { more chronic or } \\
\text { disability } \\
\text { conditions) }\end{array}$} & sick & $50 \%$ & 0.50 & 128,040 \\
\hline & No sick & $50 \%$ & 0.50 & 128,040 \\
\hline $\begin{array}{l}\text { Living in rural } \\
\text { areas }\end{array}$ & Rural & $3.96 \%$ & 0.20 & 128,040 \\
\hline
\end{tabular}




\begin{tabular}{|c|c|c|c|c|}
\hline & No rural & $96.04 \%$ & 0.20 & 128,040 \\
\hline \multirow{2}{*}{$\begin{array}{l}\text { Family } \\
\text { members in bad } \\
\text { health }\end{array}$} & Nohealthrel & $21.08 \%$ & 0.41 & 128,040 \\
\hline & Healthrel & $78.92 \%$ & 0.41 & 128,040 \\
\hline \multirow[t]{5}{*}{ Marital Status } & Single & $34.16 \%$ & 0.47 & 128,040 \\
\hline & Married & $47.93 \%$ & 0.50 & 128,040 \\
\hline & Separated & $3.00 \%$ & 0.17 & 128,040 \\
\hline & Divorced & $1.46 \%$ & 0.12 & 128,040 \\
\hline & Widow & $8.07 \%$ & 0.27 & 128,040 \\
\hline \multirow{2}{*}{$\begin{array}{l}\text { House Problems } \\
\text { (Lighting, } \\
\text { Humidity, } \\
\text { Heating } \\
\text { shortage) }\end{array}$} & Houseproblems & $3.98 \%$ & 0.20 & 128,040 \\
\hline & $\begin{array}{l}\text { No House } \\
\text { problems }\end{array}$ & $96.02 \%$ & 0.20 & 128,040 \\
\hline \multirow{8}{*}{$\begin{array}{c}\text { Relational } \\
\text { Goods (Feeling } \\
\text { of absence of } \\
\text { relatives,friends, } \\
\text { neighbours and } \\
\text { volunteer } \\
\text { organizations) }\end{array}$} & Norel & $15.98 \%$ & 0.37 & 128,040 \\
\hline & Yesrel & $84.02 \%$ & 0.37 & 128,040 \\
\hline & Nofriend & $37.35 \%$ & 0.48 & 128,040 \\
\hline & Yesfriend & $62.65 \%$ & 0.48 & 128,040 \\
\hline & Noneigh & $51.32 \%$ & 0.50 & 128,040 \\
\hline & Yesneigh & $48.68 \%$ & 0.50 & 128,040 \\
\hline & Novoulun & $87.83 \%$ & 0.33 & 128,040 \\
\hline & Yesvoulun & $12.17 \%$ & 0.33 & 128,040 \\
\hline $\begin{array}{l}\text { Proportion of } \\
\text { rich in the } \\
\text { reference group }\end{array}$ & Meanpoor & 36.39 & 0.03 & 128,040 \\
\hline $\begin{array}{l}\text { Proportion of } \\
\text { sick in the } \\
\text { reference group }\end{array}$ & meansick & 53.35 & 0.24 & 128,040 \\
\hline \multirow{2}{*}{$\begin{array}{l}\text { Medical visit in } \\
\text { the last four } \\
\text { weeks }\end{array}$} & Visit & $16.46 \%$ & 0.37 & 128,040 \\
\hline & No Visit & $83.54 \%$ & 0.37 & 128,040 \\
\hline $\begin{array}{l}\text { Hospitalization } \\
\text { days in the last } \\
\text { three months }\end{array}$ & Hospitalization & 0.275 & 2.56 & 128,040 \\
\hline
\end{tabular}


Table 2A. Estimates Results (All Covariates)

\begin{tabular}{|c|c|c|c|c|}
\hline & (1) & (2) & (3) & (4) \\
\hline & $\begin{array}{l}\text { Happiness } \\
\text { OLS }\end{array}$ & $\begin{array}{c}\text { Happiness } \\
\text { Ordered Probit }\end{array}$ & $\begin{array}{c}\text { Subjective Health } \\
\text { OLS }\end{array}$ & $\begin{array}{c}\text { Subjective Health } \\
\text { Ordered Probit }\end{array}$ \\
\hline male & $\begin{array}{c}0.148 * * * \\
(16.88)\end{array}$ & $\begin{array}{l}0.132 * * * \\
(16.53)\end{array}$ & $\begin{array}{l}0.0920 * * * \\
(17.98)\end{array}$ & $\begin{array}{c}0.160 * * * \\
(17.87)\end{array}$ \\
\hline eta & $\begin{array}{c}-0.0757 * * * \\
(-12.11)\end{array}$ & $\begin{array}{c}-0.0726 * * * \\
(-12.12)\end{array}$ & $\begin{array}{c}-0.0311 * * * \\
(-10.14)\end{array}$ & $\begin{array}{c}-0.0582 * * * \\
(-10.15)\end{array}$ \\
\hline eta2 & $\begin{array}{l}0.00123 * * * \\
(9.71)\end{array}$ & $\begin{array}{l}0.00120 * * * \\
(9.99)\end{array}$ & $\begin{array}{c}0.000396 * * * \\
(5.96)\end{array}$ & $\begin{array}{c}0.000763 * * * \\
(6.28)\end{array}$ \\
\hline eta3 & $\begin{array}{c}-0.00000712 * * * \\
(-9.06)\end{array}$ & $\begin{array}{c}-0.00000695 * * * \\
(-9.40)\end{array}$ & $\begin{array}{c}-0.00000230 * * * \\
(-5.24)\end{array}$ & $\begin{array}{c}-0.00000433 * * * \\
(-5.50)\end{array}$ \\
\hline primary & $\begin{array}{l}0.0777 * * * \\
(3.87)\end{array}$ & $\begin{array}{c}0.0682 * * * \\
(3.85)\end{array}$ & $\begin{array}{l}0.0693 * * * \\
(7.06)\end{array}$ & $\begin{array}{c}0.113 * * * \\
(6.90)\end{array}$ \\
\hline junior & $\begin{array}{l}0.107 * * * \\
\quad(5.14)\end{array}$ & $\begin{array}{l}0.0914 * * * \\
\quad(4.96)\end{array}$ & $\begin{array}{l}0.113 * * * \\
\quad(9.80)\end{array}$ & $\begin{array}{l}0.184 * * * \\
\quad(9.40)\end{array}$ \\
\hline high & $\begin{array}{l}0.0893 * * * \\
\quad(4.05)\end{array}$ & $\begin{array}{l}0.0742 * * * \\
(3.80)\end{array}$ & $\begin{array}{c}0.174 * * * \\
(15.03)\end{array}$ & $\begin{array}{c}0.289 * * * \\
(14.82)\end{array}$ \\
\hline college & $\begin{array}{c}0.0134 \\
(0.52)\end{array}$ & $\begin{array}{c}0.00729 \\
(0.32)\end{array}$ & $\begin{array}{c}0.251 * * * \\
(17.50)\end{array}$ & $\begin{array}{c}0.422 * * * \\
(17.16)\end{array}$ \\
\hline Optimum circ. & $\begin{array}{c}0.529 * * * \\
(18.38)\end{array}$ & $\begin{array}{c}0.475 * * * \\
(18.13)\end{array}$ & $\begin{array}{c}0.305 * * * \\
(17.00)\end{array}$ & $\begin{array}{c}0.523 * * * \\
(17.13)\end{array}$ \\
\hline Fair circ. & $\begin{array}{c}0.401 * * * \\
(17.69)\end{array}$ & $\begin{array}{c}0.352 * * * \\
(17.12)\end{array}$ & $\begin{array}{c}0.200 * * * \\
(13.47)\end{array}$ & $\begin{array}{c}0.332 * * * \\
(13.47)\end{array}$ \\
\hline Insufficient circ. & $\begin{array}{c}0.129 * * * \\
(5.86)\end{array}$ & $\begin{array}{l}0.114 * * * \\
(5.73)\end{array}$ & $\begin{array}{l}0.0869 * * * \\
(6.24)\end{array}$ & $\begin{array}{c}0.140 * * * \\
(6.06)\end{array}$ \\
\hline employed & $\begin{array}{c}0.0875^{* * * *} \\
(3.99)\end{array}$ & $\begin{array}{c}0.0764 * * * \\
(3.81)\end{array}$ & $\begin{array}{c}0.00380 \\
(0.29)\end{array}$ & $\begin{array}{c}0.000276 \\
(0.01)\end{array}$ \\
\hline retired & $\begin{array}{c}0.221 * * * \\
(6.69)\end{array}$ & $\begin{array}{c}0.193 * * * \\
(6.51)\end{array}$ & $\begin{array}{c}-0.00446 \\
(-0.23)\end{array}$ & $\begin{array}{c}-0.0151 \\
(-0.45)\end{array}$ \\
\hline other_occup & $\begin{array}{c}0.0512 \\
(1.22)\end{array}$ & $\begin{array}{c}0.0419 \\
(1.12)\end{array}$ & $\begin{array}{c}-0.138 * * * \\
(-5.53)\end{array}$ & $\begin{array}{c}-0.226 * * * \\
(-5.62)\end{array}$ \\
\hline unable & $\begin{array}{c}-0.517 * * * \\
(-8.97)\end{array}$ & $\begin{array}{c}-0.485 * * * \\
(-8.86)\end{array}$ & $\begin{array}{c}-0.709 * * * \\
(-19.12)\end{array}$ & $\begin{array}{c}-1.028 * * * \\
(-17.44)\end{array}$ \\
\hline housekeeper & $\begin{array}{c}0.184 * * * \\
(6.58)\end{array}$ & $\begin{array}{c}0.163 * * * \\
(6.37)\end{array}$ & $\begin{array}{c}0.0189 \\
(1.20)\end{array}$ & $\begin{array}{c}0.0272 \\
(0.99)\end{array}$ \\
\hline sick & $\begin{array}{c}-0.264 * * * \\
(-11.24)\end{array}$ & $\begin{array}{c}-0.261 * * * \\
(-11.95)\end{array}$ & $\begin{array}{c}-0.299 * * * \\
(-21.08)\end{array}$ & $\begin{array}{c}-0.563 * * * \\
(-22.87)\end{array}$ \\
\hline rural & $\begin{array}{c}0.0124 \\
(0.46)\end{array}$ & $\begin{array}{c}0.00903 \\
(0.38)\end{array}$ & $\begin{array}{c}0.00223 \\
(0.11)\end{array}$ & $\begin{array}{c}-0.000325 \\
(-0.01)\end{array}$ \\
\hline Nohealthrel & $\begin{array}{c}-0.230 * * * \\
(-25.14)\end{array}$ & $\begin{array}{c}-0.205^{* * *} \\
(-25.14)\end{array}$ & $\begin{array}{c}-0.0722 * * * \\
(-13.69)\end{array}$ & $\begin{array}{c}-0.124 * * * \\
(-13.78)\end{array}$ \\
\hline married & $\begin{array}{c}0.150 * * * \\
(11.46)\end{array}$ & $\begin{array}{c}0.133 * * * \\
(11.35)\end{array}$ & $\begin{array}{c}-0.0348 * * * \\
(-4.93)\end{array}$ & $\begin{array}{c}-0.0587 * * * \\
(-4.79)\end{array}$ \\
\hline Separ. & $\begin{array}{c}-0.0413 * \\
(-1.67)\end{array}$ & $\begin{array}{c}-0.0342 \\
(-1.56)\end{array}$ & $\begin{array}{c}0.000433 \\
(0.03)\end{array}$ & $\begin{array}{c}0.00126 \\
(0.06)\end{array}$ \\
\hline divorced & $\begin{array}{c}-0.0661 * * \\
(-2.01)\end{array}$ & $\begin{array}{c}-0.0559^{*} \\
(-1.95)\end{array}$ & $\begin{array}{c}-0.0173 \\
(-0.92)\end{array}$ & $\begin{array}{c}-0.0255 \\
(-0.80)\end{array}$ \\
\hline Widow & $\begin{array}{c}-0.119 * * * \\
(-5.70)\end{array}$ & $\begin{array}{c}-0.102 * * * \\
(-5.58)\end{array}$ & $\begin{array}{c}-0.0242 * * \\
(-2.19)\end{array}$ & $\begin{array}{c}-0.0371 * * \\
(-2.02)\end{array}$ \\
\hline houseproblems & $\begin{array}{c}-0.170 * * * \\
(-8.52)\end{array}$ & $\begin{array}{c}-0.150 * * * \\
(-8.46)\end{array}$ & $\begin{array}{c}-0.0574 * * * \\
(-5.20)\end{array}$ & $\begin{array}{c}-0.0977 * * * \\
(-5.27)\end{array}$ \\
\hline Norel & $\begin{array}{c}-0.0988 * * * \\
(-9.37)\end{array}$ & $\begin{array}{c}-0.0863 * * * \\
(-9.08)\end{array}$ & $\begin{array}{c}-0.0230 * * * \\
(-3.91)\end{array}$ & $\begin{array}{c}-0.0393 * * * \\
(-3.95)\end{array}$ \\
\hline Nofriend & $\begin{array}{c}-0.0477 * * * \\
(-4.79)\end{array}$ & $\begin{array}{c}-0.0429 * * * \\
(-4.82)\end{array}$ & $\begin{array}{c}-0.0381 * * * \\
(-7.84)\end{array}$ & $\begin{array}{c}-0.0647 * * * \\
(-7.75)\end{array}$ \\
\hline Noneigh & $-0.0431 * * *$ & $-0.0400 * * *$ & -0.00223 & -0.00328 \\
\hline
\end{tabular}


Social Comparison And Subjective Well-being

\begin{tabular}{|c|c|c|c|c|}
\hline & $(-4.88)$ & $(-5.10)$ & $(-0.49)$ & $(-0.42)$ \\
\hline Novoulun & $\begin{array}{c}-0.0369 * * * \\
(-3.04)\end{array}$ & $\begin{array}{c}-0.0327 * * * \\
(-2.98)\end{array}$ & $\begin{array}{c}0.0124^{*} \\
(1.84)\end{array}$ & $\begin{array}{c}0.0211^{*} \\
(1.81)\end{array}$ \\
\hline meansick & $\begin{array}{c}-0.359^{* * * *} \\
(-4.96)\end{array}$ & $\begin{array}{c}-0.362^{* * *} \\
(-5.39)\end{array}$ & $\begin{array}{c}-0.293^{* * *} \\
(-6.93)\end{array}$ & $\begin{array}{c}-0.573 * * * \\
(-7.62)\end{array}$ \\
\hline sick_meansick & $\begin{array}{c}-0.255^{* * * *} \\
(-5.63)\end{array}$ & $\begin{array}{c}-0.176^{* * * *} \\
(-4.20)\end{array}$ & $\begin{array}{c}-0.251 * * * \\
(-10.09)\end{array}$ & $\begin{array}{c}-0.320 * * * \\
(-7.30)\end{array}$ \\
\hline Visit & & & $\begin{array}{c}-0.220 * * * \\
(-37.28)\end{array}$ & $\begin{array}{c}-0.366 * * * \\
(-38.14)\end{array}$ \\
\hline Hosp. days & & & $\begin{array}{c}-0.0268 * * * \\
(-20.55)\end{array}$ & $\begin{array}{c}-0.0435 * * * \\
(-18.80)\end{array}$ \\
\hline _cons & $\begin{array}{c}5.516 * * * \\
(59.67)\end{array}$ & & $\begin{array}{c}4.706 * * * \\
(106.63)\end{array}$ & \\
\hline cut1 & & & & \\
\hline _cons & & $\begin{array}{c}-3.625 * * * \\
(-39.91)\end{array}$ & & $\begin{array}{c}-5.000 * * * \\
(-58.84)\end{array}$ \\
\hline cut2 & & & & \\
\hline _cons & & $\begin{array}{c}-2.788^{* * * *} \\
(-30.64)\end{array}$ & & $\begin{array}{c}-3.937 * * * \\
(-46.38)\end{array}$ \\
\hline cut3 & & & & \\
\hline _cons & & $\begin{array}{c}-1.694 * * * \\
(-18.69)\end{array}$ & & $\begin{array}{c}-2.167 * * * \\
(-25.54)\end{array}$ \\
\hline cut 4 & & & & \\
\hline _cons & & $\begin{array}{c}-1.264 * * * \\
(-13.89)\end{array}$ & & $\begin{array}{c}-0.556 * * * \\
(-6.49)\end{array}$ \\
\hline $\begin{array}{l}\text { cut5 } \\
\text { cons }\end{array}$ & & $\begin{array}{l}-0.122 \\
(-1.34)\end{array}$ & & \\
\hline $\begin{array}{l}\mathrm{N} \\
\text { Adjusted } \mathrm{R}^{2}\end{array}$ & $\begin{array}{c}104342 \\
0.167\end{array}$ & 104342 & $\begin{array}{c}109129 \\
0.431\end{array}$ & 109129 \\
\hline $\begin{array}{l}\text { Log-Likelihood } \\
\text { Chi-square stat. }\end{array}$ & -164372.1 & $\begin{array}{c}-153523.0 \\
13011.2\end{array}$ & -108502.7 & $\begin{array}{c}-106223.2 \\
30249.1\end{array}$ \\
\hline
\end{tabular}

$t$ statistics in parentheses. Standard errors are clustered on 464 reference groups

$* p<.10, * * p<.05, * * * p<0.01$ 
Table 3A. Robustness Check (All covariates )

\begin{tabular}{|c|c|c|c|c|}
\hline & $\begin{array}{l}(1) \\
\text { Happiness } \\
\text { OLS }\end{array}$ & $\begin{array}{c}\text { (2) } \\
\text { Happiness } \\
\text { Ordered Probit }\end{array}$ & $\begin{array}{c}(3) \\
\text { Subjective Health } \\
\text { OLS }\end{array}$ & $\begin{array}{c}(4) \\
\text { Subjective Health } \\
\text { Ordered Probit }\end{array}$ \\
\hline male & $\begin{array}{c}0.147 * * * \\
(16.90)\end{array}$ & $\begin{array}{c}0.132 * * * \\
(16.54)\end{array}$ & $\begin{array}{l}0.0921 * * * \\
(18.03)\end{array}$ & $\begin{array}{c}0.160 * * * \\
(17.91)\end{array}$ \\
\hline eta & $\begin{array}{c}-0.0753 * * * \\
(-12.04)\end{array}$ & $\begin{array}{c}-0.0721 * * * \\
(-12.03)\end{array}$ & $\begin{array}{c}-0.0315 * * * \\
(-10.29)\end{array}$ & $\begin{array}{c}-0.0589 * * * \\
(-10.28)\end{array}$ \\
\hline eta2 & $\begin{array}{c}0.00122 * * * \\
(9.62)\end{array}$ & $\begin{array}{c}0.00118 * * * \\
(9.87)\end{array}$ & $\begin{array}{c}0.000406^{* * * *} \\
(6.13)\end{array}$ & $\begin{array}{c}0.000780 * * * \\
(6.43)\end{array}$ \\
\hline eta3 & $\begin{array}{c}-0.00000707 * * * \\
(-8.96)\end{array}$ & $\begin{array}{c}-0.00000688^{* * * *} \\
(-9.29)\end{array}$ & $\begin{array}{c}-0.00000237 * * * \\
(-5.40)\end{array}$ & $\begin{array}{c}-0.00000444 * * * \\
(-5.64)\end{array}$ \\
\hline primary & $\begin{array}{l}0.0778 * * * \\
\quad(3.87)\end{array}$ & $\begin{array}{l}0.0683 * * * \\
(3.86)\end{array}$ & $\begin{array}{l}0.0693 * * * \\
(7.08)\end{array}$ & $\begin{array}{c}0.113 * * * \\
(6.91)\end{array}$ \\
\hline junior & $\begin{array}{c}0.107 * * * \\
(5.14)\end{array}$ & $\begin{array}{c}0.0913 * * * \\
(4.95)\end{array}$ & $\begin{array}{c}0.113 * * * \\
(9.85)\end{array}$ & $\begin{array}{c}0.185 * * * \\
(9.44)\end{array}$ \\
\hline high & $\begin{array}{l}0.0880 * * * \\
(3.97)\end{array}$ & $\begin{array}{c}0.0725 * * * \\
\quad(3.69)\end{array}$ & $\begin{array}{c}0.176 * * * \\
(15.29)\end{array}$ & $\begin{array}{c}0.292 * * * \\
(15.08)\end{array}$ \\
\hline college & $\begin{array}{c}0.00900 \\
(0.35)\end{array}$ & $\begin{array}{c}0.00177 \\
(0.08)\end{array}$ & $\begin{array}{c}0.257 * * * \\
(17.70)\end{array}$ & $\begin{array}{c}0.433 * * * \\
(17.38)\end{array}$ \\
\hline Optimum circ. & $\begin{array}{c}0.527 * * * \\
(18.13)\end{array}$ & $\begin{array}{c}0.472 * * * \\
(17.89)\end{array}$ & $\begin{array}{c}0.308 * * * \\
(17.13)\end{array}$ & $\begin{array}{c}0.527 * * * \\
(17.28)\end{array}$ \\
\hline fairinc & $\begin{array}{c}0.401 * * * \\
(17.68)\end{array}$ & $\begin{array}{c}0.352 * * * \\
(17.11)\end{array}$ & $\begin{array}{c}0.201 * * * \\
(13.48)\end{array}$ & $\begin{array}{c}0.332 * * * \\
(13.49)\end{array}$ \\
\hline badinc & $\begin{array}{c}0.129 * * * \\
(5.86)\end{array}$ & $\begin{array}{c}0.114 * * * \\
(5.73)\end{array}$ & $\begin{array}{l}0.0869 * * * \\
(6.24)\end{array}$ & $\begin{array}{c}0.140 * * * \\
(6.06)\end{array}$ \\
\hline employed & $\begin{array}{l}0.0875 * * * \\
\quad(3.99)\end{array}$ & $\begin{array}{l}0.0762 * * * \\
\quad(3.80)\end{array}$ & $\begin{array}{c}0.00381 \\
(0.29)\end{array}$ & $\begin{array}{l}0.000334 \\
(0.01)\end{array}$ \\
\hline retired & $\begin{array}{c}0.222 * * * \\
(6.72)\end{array}$ & $\begin{array}{c}0.194 * * * \\
(6.55)\end{array}$ & $\begin{array}{c}-0.00558 \\
(-0.29)\end{array}$ & $\begin{array}{c}-0.0168 \\
(-0.51)\end{array}$ \\
\hline other_occup & $\begin{array}{c}0.0506 \\
(1.20)\end{array}$ & $\begin{array}{c}0.0411 \\
(1.10)\end{array}$ & $\begin{array}{c}-0.137 * * * \\
(-5.46)\end{array}$ & $\begin{array}{c}-0.225 * * * \\
(-5.54)\end{array}$ \\
\hline unable & $\begin{array}{c}-0.517 * * * \\
(-9.01)\end{array}$ & $\begin{array}{c}-0.485 * * * \\
(-8.92)\end{array}$ & $\begin{array}{c}-0.709 * * * \\
(-19.03)\end{array}$ & $\begin{array}{c}-1.028 * * * \\
(-17.38)\end{array}$ \\
\hline housekeeper & $\begin{array}{l}0.184 * * * \\
(6.58)\end{array}$ & $\begin{array}{c}0.163 * * * \\
(6.37)\end{array}$ & $\begin{array}{c}0.0185 \\
(1.17)\end{array}$ & $\begin{array}{c}0.0267 \\
(0.97)\end{array}$ \\
\hline sick & $\begin{array}{c}-0.264 * * * \\
(-11.25)\end{array}$ & $\begin{array}{c}-0.261 * * * \\
(-11.97)\end{array}$ & $\begin{array}{c}-0.298 * * * \\
(-21.06)\end{array}$ & $\begin{array}{c}-0.562 * * * \\
(-22.85)\end{array}$ \\
\hline rural & $\begin{array}{c}0.0132 \\
(0.50)\end{array}$ & $\begin{array}{c}0.0101 \\
(0.42)\end{array}$ & $\begin{array}{c}0.00107 \\
(0.05)\end{array}$ & $\begin{array}{c}-0.00223 \\
(-0.06)\end{array}$ \\
\hline Nohealthrel & $\begin{array}{c}-0.230 * * * \\
(-25.13)\end{array}$ & $\begin{array}{c}-0.205 * * * \\
(-25.14)\end{array}$ & $\begin{array}{c}-0.0722 * * * \\
(-13.69)\end{array}$ & $\begin{array}{c}-0.124 * * * \\
(-13.78)\end{array}$ \\
\hline married & $\begin{array}{c}0.150 * * * \\
(11.42)\end{array}$ & $\begin{array}{c}0.132 * * * \\
(11.31)\end{array}$ & $\begin{array}{c}-0.0345^{* * *} \\
(-4.90)\end{array}$ & $\begin{array}{c}-0.0582 * * * \\
(-4.76)\end{array}$ \\
\hline separ & $\begin{array}{c}-0.0415^{*} \\
(-1.68)\end{array}$ & $\begin{array}{c}-0.0345 \\
(-1.58)\end{array}$ & $\begin{array}{c}0.000690 \\
(0.05)\end{array}$ & $\begin{array}{c}0.00168 \\
(0.07)\end{array}$ \\
\hline divorced & $\begin{array}{c}-0.0664 * * \\
(-2.02)\end{array}$ & $\begin{array}{c}-0.0562^{*} \\
(-1.96)\end{array}$ & $\begin{array}{c}-0.0170 \\
(-0.90)\end{array}$ & $\begin{array}{c}-0.0250 \\
(-0.79)\end{array}$ \\
\hline widow & $\begin{array}{c}-0.119 * * * \\
(-5.70)\end{array}$ & $\begin{array}{c}-0.103 * * * \\
(-5.58)\end{array}$ & $\begin{array}{c}-0.0241 * * \\
(-2.18)\end{array}$ & $\begin{array}{c}-0.0369 * * \\
(-2.02)\end{array}$ \\
\hline houseproblems & $\begin{array}{c}-0.170 * * * \\
(-8.52)\end{array}$ & $\begin{array}{c}-0.150 * * * \\
(-8.47)\end{array}$ & $\begin{array}{c}-0.0574 * * * \\
(-5.19)\end{array}$ & $\begin{array}{c}-0.0977 * * * \\
(-5.26)\end{array}$ \\
\hline Norel & $\begin{array}{c}-0.0988 * * * \\
(-9.37)\end{array}$ & $\begin{array}{c}-0.0863 * * * \\
(-9.08)\end{array}$ & $\begin{array}{c}-0.0230 * * * \\
(-3.91)\end{array}$ & $\begin{array}{c}-0.0392 * * * \\
(-3.95)\end{array}$ \\
\hline Nofriend & $\begin{array}{c}-0.0477 * * * \\
(-4.79)\end{array}$ & $\begin{array}{c}-0.0428 * * * \\
(-4.82)\end{array}$ & $\begin{array}{c}-0.0382 * * * \\
(-7.85)\end{array}$ & $\begin{array}{c}-0.0648 * * * \\
(-7.76)\end{array}$ \\
\hline noneigh & $-0.0430 * * *$ & $-0.0399 * * *$ & -0.00236 & -0.00348 \\
\hline
\end{tabular}


Social Comparison And Subjective Well-being

\begin{tabular}{|c|c|c|c|c|}
\hline & $(-4.87)$ & $(-5.09)$ & $(-0.51)$ & $(-0.44)$ \\
\hline novoulun & $\begin{array}{c}-0.0370 * * * \\
(-306)\end{array}$ & $\begin{array}{c}-0.0328 * * * * \\
(-299)\end{array}$ & $0.0126^{*}$ & $0.0213^{*}$ \\
\hline meanrich & $\begin{array}{l}0.117 \\
(0.58)\end{array}$ & $\begin{array}{l}0.146 \\
(0.82)\end{array}$ & $\begin{array}{c}-0.162 * \\
(-1.72)\end{array}$ & $\begin{array}{c}-0.267^{*} \\
(-1.66)\end{array}$ \\
\hline meansick & $\begin{array}{c}-0.354 * * * \\
(-4.88)\end{array}$ & $\begin{array}{c}-0.356^{* * *} \\
(-5.28)\end{array}$ & $\begin{array}{c}-0.299 * * * \\
(-7.03)\end{array}$ & $\begin{array}{c}-0.584 * * * \\
(-7.71)\end{array}$ \\
\hline sick_meansick & $\begin{array}{c}-0.254 * * * \\
(-5.62)\end{array}$ & $\begin{array}{c}-0.175 * * * \\
(-4.18)\end{array}$ & $\begin{array}{c}-0.251 * * * \\
(-10.11)\end{array}$ & $\begin{array}{c}-0.320 * * * \\
(-7.32)\end{array}$ \\
\hline visit & & & $\begin{array}{c}-0.220 * * * * \\
(-37.27)\end{array}$ & $\begin{array}{c}-0.366^{* * * *} \\
(-38.13)\end{array}$ \\
\hline Hosp. days & & & $\begin{array}{c}-0.0268 * * * \\
(-20.54)\end{array}$ & $\begin{array}{c}-0.0435 * * * \\
(-18.79)\end{array}$ \\
\hline _cons & $\begin{array}{c}5.508 * * * \\
(58.77)\end{array}$ & & $\begin{array}{c}4.717 * * * \\
(106.31)\end{array}$ & \\
\hline cut1 & & & & \\
\hline _cons & & $\begin{array}{c}-3.614 * * * * \\
(-39.42)\end{array}$ & & $\begin{array}{c}-5.018^{* * * *} \\
(-58.97)\end{array}$ \\
\hline cut 2 & & & & \\
\hline _cons & & $\begin{array}{c}-2.778 * * * \\
(-30.21)\end{array}$ & & $\begin{array}{c}-3.954 * * * \\
(-46.40)\end{array}$ \\
\hline cut3 & & & & \\
\hline _cons & & $\begin{array}{c}-1.683 * * * \\
(-18.38)\end{array}$ & & $\begin{array}{c}-2.185 * * * \\
(-25.62)\end{array}$ \\
\hline cut 4 & & & & \\
\hline _cons & & $\begin{array}{c}-1.253 * * * \\
(-13.64)\end{array}$ & & $\begin{array}{c}-0.573 * * * \\
(-6.66)\end{array}$ \\
\hline $\begin{array}{l}\text { cut5 } \\
\text { _cons }\end{array}$ & & $\begin{array}{l}-0.111 \\
(-1.21)\end{array}$ & & \\
\hline $\begin{array}{l}\mathrm{N} \\
\text { Adjusted } \mathrm{R}^{2} \\
\text { Log-likelihood } \\
\text { Chi-square stat. }\end{array}$ & $\begin{array}{c}104342 \\
0.167 \\
-164371.8\end{array}$ & $\begin{array}{c}-153522.5 \\
13039.6\end{array}$ & $\begin{array}{c}109129 \\
0.432 \\
-108500.9\end{array}$ & $\begin{array}{c}-106221.5 \\
30091.6\end{array}$ \\
\hline
\end{tabular}

$t$ statistics in parentheses. Standard errors are clustered on 464 reference groups

$* p<.10, * * p<.05, * * * p<0.01$ 
Table 4A. Estimates Results. People living in the South (All covariates )

\begin{tabular}{|c|c|c|c|c|}
\hline & $\begin{array}{l}(1) \\
\text { Happiness } \\
\text { OLS }\end{array}$ & $\begin{array}{c}(2) \\
\text { Happiness } \\
\text { Ordered Probit }\end{array}$ & $\begin{array}{c}\text { (3) } \\
\text { Subjective Health } \\
\text { OLS }\end{array}$ & $\begin{array}{c}\text { (4) } \\
\text { Subjective Health } \\
\text { Ordered Probit }\end{array}$ \\
\hline \multicolumn{5}{|l|}{ main } \\
\hline male & $\begin{array}{l}0.129 * * * \\
(9.84)\end{array}$ & $\begin{array}{l}0.118 * * * \\
\quad(9.71)\end{array}$ & $\begin{array}{c}0.101 * * * \\
(11.55)\end{array}$ & $\begin{array}{c}0.178 * * * \\
(11.68)\end{array}$ \\
\hline eta & $\begin{array}{c}-0.0838 * * * \\
(-9.76)\end{array}$ & $\begin{array}{c}-0.0841 * * * \\
(-10.30)\end{array}$ & $\begin{array}{c}-0.0341 * * * \\
(-10.69)\end{array}$ & $\begin{array}{c}-0.0662 * * * \\
(-11.48)\end{array}$ \\
\hline eta2 & $\begin{array}{c}0.00124 * * * \\
(6.72)\end{array}$ & $\begin{array}{c}0.00128 * * * \\
(7.40)\end{array}$ & $\begin{array}{c}0.000464 * * * \\
(6.39)\end{array}$ & $\begin{array}{c}0.000936 * * * \\
(7.37)\end{array}$ \\
\hline eta3 & $\begin{array}{c}-0.00000699 * * * \\
(-5.95)\end{array}$ & $\begin{array}{c}-0.00000726 * * * \\
(-6.61)\end{array}$ & $\begin{array}{c}-0.00000287 * * * \\
(-5.79)\end{array}$ & $\begin{array}{c}-0.00000560 * * * \\
(-6.64)\end{array}$ \\
\hline primary & $\begin{array}{c}-0.00553 \\
(-0.21)\end{array}$ & $\begin{array}{c}-0.00445 \\
(-0.20)\end{array}$ & $\begin{array}{c}0.0264^{*} \\
(1.80)\end{array}$ & $\begin{array}{c}0.0409 * \\
(1.68)\end{array}$ \\
\hline junior & $\begin{array}{c}0.0636 * * \\
(2.33)\end{array}$ & $\begin{array}{c}0.0555^{* *} \\
(2.30)\end{array}$ & $\begin{array}{l}0.0680 * * * \\
(4.09)\end{array}$ & $\begin{array}{c}0.109 * * * \\
(3.89)\end{array}$ \\
\hline high & $\begin{array}{l}0.0772 * * * \\
\quad(2.67)\end{array}$ & $\begin{array}{c}0.0657 * * \\
(2.53)\end{array}$ & $\begin{array}{c}0.142 * * * \\
(7.83)\end{array}$ & $\begin{array}{l}0.233 * * * \\
(7.76)\end{array}$ \\
\hline college & $\begin{array}{c}0.0155 \\
(0.38)\end{array}$ & $\begin{array}{c}0.00984 \\
(0.26)\end{array}$ & $\begin{array}{c}0.209 * * * \\
(8.91)\end{array}$ & $\begin{array}{l}0.349 * * * \\
(8.76)\end{array}$ \\
\hline Optimum circ. & $\begin{array}{c}0.521 * * * \\
(14.27)\end{array}$ & $\begin{array}{c}0.472 * * * \\
(13.70)\end{array}$ & $\begin{array}{c}0.284 * * * \\
(11.53)\end{array}$ & $\begin{array}{c}0.497 * * * \\
(11.62)\end{array}$ \\
\hline fairinc & $\begin{array}{c}0.398 * * * \\
(15.13)\end{array}$ & $\begin{array}{c}0.354 * * * \\
(14.50)\end{array}$ & $\begin{array}{c}0.155 * * * \\
(8.31)\end{array}$ & $\begin{array}{c}0.257 * * * \\
(8.29)\end{array}$ \\
\hline badinc & $\begin{array}{c}0.132 * * * \\
(4.96)\end{array}$ & $\begin{array}{c}0.118 * * * \\
(4.83)\end{array}$ & $\begin{array}{l}0.0598 * * * \\
(3.33)\end{array}$ & $\begin{array}{l}0.0942 * * * \\
(3.15)\end{array}$ \\
\hline employed & $\begin{array}{c}0.122 * * * \\
(4.11)\end{array}$ & $\begin{array}{c}0.109 * * * \\
(4.00)\end{array}$ & $\begin{array}{c}0.0469 * * * \\
(3.15)\end{array}$ & $\begin{array}{l}0.0771 * * * \\
(2.89)\end{array}$ \\
\hline retired & $\begin{array}{l}0.142 * * * \\
\quad(3.02)\end{array}$ & $\begin{array}{c}0.126 * * * \\
(2.99)\end{array}$ & $\begin{array}{c}0.0320 \\
(1.46)\end{array}$ & $\begin{array}{c}0.0473 \\
(1.27)\end{array}$ \\
\hline other_occup & $\begin{array}{c}-0.0115 \\
(-0.21)\end{array}$ & $\begin{array}{c}-0.00822 \\
(-0.17)\end{array}$ & $\begin{array}{c}-0.0344 \\
(-1.06)\end{array}$ & $\begin{array}{c}-0.0534 \\
(-1.02)\end{array}$ \\
\hline unable & $\begin{array}{c}-0.600 * * * \\
(-8.66)\end{array}$ & $\begin{array}{c}-0.562 * * * \\
(-8.48)\end{array}$ & $\begin{array}{c}-0.571 * * * \\
(-11.08)\end{array}$ & $\begin{array}{c}-0.806 * * * \\
(-10.10)\end{array}$ \\
\hline housekeeper & $\begin{array}{c}0.141 * * * \\
(3.94)\end{array}$ & $\begin{array}{c}0.130 * * * \\
(3.96)\end{array}$ & $\begin{array}{c}0.0751 * * * \\
(4.09)\end{array}$ & $\begin{array}{c}0.127 * * * \\
(4.03)\end{array}$ \\
\hline sick & $\begin{array}{c}-0.288 * * * \\
(-9.05)\end{array}$ & $\begin{array}{c}-0.284 * * * \\
(-9.81)\end{array}$ & $\begin{array}{c}-0.347 * * * \\
(-17.50)\end{array}$ & $\begin{array}{c}-0.637 * * * \\
(-19.34)\end{array}$ \\
\hline Rural & $\begin{array}{c}0.00867 \\
(0.23)\end{array}$ & $\begin{array}{c}-0.00230 \\
(-0.07)\end{array}$ & $\begin{array}{c}0.0382 * * \\
(1.99)\end{array}$ & $\begin{array}{c}0.0637 * \\
(1.96)\end{array}$ \\
\hline Nohealthrel & $\begin{array}{c}-0.260 * * * \\
(-17.31)\end{array}$ & $\begin{array}{c}-0.235^{* * * *} \\
(-17.37)\end{array}$ & $\begin{array}{c}-0.0875 * * * \\
(-10.45)\end{array}$ & $\begin{array}{c}-0.149 * * * \\
(-10.43)\end{array}$ \\
\hline Married & $\begin{array}{c}0.124 * * * \\
(5.73)\end{array}$ & $\begin{array}{c}0.113 * * * \\
(5.85)\end{array}$ & $\begin{array}{c}-0.0711 * * * \\
(-6.81)\end{array}$ & $\begin{array}{c}-0.118 * * * \\
(-6.53)\end{array}$ \\
\hline Separ & $\begin{array}{c}-0.0881^{*} \\
(-1.89)\end{array}$ & $\begin{array}{c}-0.0778^{*} \\
(-1.88)\end{array}$ & $\begin{array}{c}-0.0414 * * \\
(-1.99)\end{array}$ & $\begin{array}{c}-0.0689 * * \\
(-1.98)\end{array}$ \\
\hline Divorced & $\begin{array}{c}-0.118 * * \\
(-2.00)\end{array}$ & $\begin{array}{c}-0.0942 * \\
(-1.79)\end{array}$ & $\begin{array}{c}-0.0226 \\
(-0.64)\end{array}$ & $\begin{array}{c}-0.0316 \\
(-0.54)\end{array}$ \\
\hline Widow & $\begin{array}{c}-0.127 * * * \\
(-4.01)\end{array}$ & $\begin{array}{c}-0.104 * * * \\
(-3.68)\end{array}$ & $\begin{array}{c}-0.0667 * * * \\
(-4.05)\end{array}$ & $\begin{array}{c}-0.105^{* * * *} \\
(-3.92)\end{array}$ \\
\hline Houseproblems & $\begin{array}{c}-0.205^{* * * *} \\
(-7.46)\end{array}$ & $\begin{array}{c}-0.182 * * * \\
(-7.42)\end{array}$ & $\begin{array}{c}-0.0521 * * * \\
(-3.69)\end{array}$ & $\begin{array}{c}-0.0878 * * * \\
(-3.73)\end{array}$ \\
\hline norel & $\begin{array}{c}-0.0754 * * * \\
(-4.53)\end{array}$ & $\begin{array}{c}-0.0661 * * * \\
(-4.30)\end{array}$ & $\begin{array}{c}-0.0212 * * \\
(-2.23)\end{array}$ & $\begin{array}{c}-0.0380^{* *} \\
(-2.33)\end{array}$ \\
\hline
\end{tabular}


Social Comparison And Subjective Well-being

\begin{tabular}{|c|c|c|c|c|}
\hline nofriend & $\begin{array}{c}-0.0615^{* * * *} \\
(-3.92)\end{array}$ & $\begin{array}{c}-0.0509 * * * \\
(-3.55)\end{array}$ & $\begin{array}{c}-0.0367 * * * \\
(-4.60)\end{array}$ & $\begin{array}{c}-0.0617 * * * \\
(-4.53)\end{array}$ \\
\hline noneigh & $\begin{array}{c}-0.00431 \\
(-0.32)\end{array}$ & $\begin{array}{c}-0.00764 \\
(-0.62)\end{array}$ & $\begin{array}{c}-0.00117 \\
(-0.15)\end{array}$ & $\begin{array}{c}-0.00149 \\
(-0.11)\end{array}$ \\
\hline novoulun & $\begin{array}{c}-0.0543 * * * \\
(-2.60)\end{array}$ & $\begin{array}{c}-0.0508^{* * *} * \\
(-2.60)\end{array}$ & $\begin{array}{c}0.0267 * * \\
(2.54)\end{array}$ & $\begin{array}{c}0.0467 * * \\
(2.58)\end{array}$ \\
\hline meanrich & $\begin{array}{l}-0.219 \\
(-0.84)\end{array}$ & $\begin{array}{l}-0.166 \\
(-0.71)\end{array}$ & $\begin{array}{c}-0.474 * * * \\
(-3.77)\end{array}$ & $\begin{array}{c}-0.790 * * * \\
(-3.69)\end{array}$ \\
\hline meansick & $\begin{array}{l}0.125 \\
(1.15)\end{array}$ & $\begin{array}{c}0.0801 \\
(0.80)\end{array}$ & $\begin{array}{c}-0.364 * * * \\
(-6.08)\end{array}$ & $\begin{array}{c}-0.680 * * * \\
(-6.59)\end{array}$ \\
\hline sick_meansick & $\begin{array}{c}-0.260 * * * \\
(-3.90)\end{array}$ & $\begin{array}{c}-0.182 * * * \\
(-3.02)\end{array}$ & $\begin{array}{c}-0.280 * * * \\
(-7.35)\end{array}$ & $\begin{array}{c}-0.353 * * * \\
(-5.57)\end{array}$ \\
\hline visit & & & $\begin{array}{c}-0.217 * * * \\
(-21.05)\end{array}$ & $\begin{array}{c}-0.356 * * * \\
(-21.66)\end{array}$ \\
\hline Hosp. days & & & $\begin{array}{c}-0.0294 * * * \\
(-12.51)\end{array}$ & $\begin{array}{c}-0.0468 * * * \\
(-10.99)\end{array}$ \\
\hline _cons & $\begin{array}{c}5.708 * * * \\
(46.56)\end{array}$ & & $\begin{array}{c}4.869 * * * \\
(99.15)\end{array}$ & \\
\hline cut1 & & & & \\
\hline _cons & & $\begin{array}{c}-3.911 * * * \\
(-32.93) \\
\end{array}$ & & $\begin{array}{c}-5.293 * * * \\
(-55.97)\end{array}$ \\
\hline cut2 & & & & \\
\hline _cons & & $\begin{array}{c}-3.009 * * * \\
(-25.43)\end{array}$ & & $\begin{array}{c}-4.213 * * * \\
(-44.48)\end{array}$ \\
\hline cut3 & & & & \\
\hline _cons & & $\begin{array}{c}-1.925 * * * \\
(-16.37) \\
\end{array}$ & & $\begin{array}{c}-2.434 * * * \\
(-25.97) \\
\end{array}$ \\
\hline cut4 & & & & \\
\hline _cons & & $\begin{array}{c}-1.500 * * * \\
(-12.77) \\
\end{array}$ & & $\begin{array}{c}-0.890 * * * \\
(-9.58) \\
\end{array}$ \\
\hline cut5 & & & & \\
\hline _cons & & $\begin{array}{c}-0.349 * * * \\
(-2.95)\end{array}$ & & \\
\hline $\mathrm{N}$ & 42223 & 42223 & 44470 & 44470 \\
\hline Adjusted $\mathrm{R}^{2}$ & $\begin{array}{c}0.201 \\
-650037\end{array}$ & & 0.484 & \\
\hline $\begin{array}{l}\text { Log-likleihood } \\
\text { Chi-square stat. }\end{array}$ & -65903.7 & $\begin{array}{c}-61285.3 \\
7524.7\end{array}$ & -44340.1 & $\begin{array}{c}-43028.6 \\
19801.2\end{array}$ \\
\hline
\end{tabular}

$t$ statistics in parentheses. Standard errors are clustered on 464 reference groups

$* p<.10, * * p<.05, * * * p<0.01$ 
Table 5A. Estimates Results. People living in the North-Center (All covariates )

\begin{tabular}{|c|c|c|c|c|}
\hline & $\begin{array}{l}(1) \\
\text { Happiness } \\
\text { OLS }\end{array}$ & $\begin{array}{c}(2) \\
\text { Happiness } \\
\text { Ordered Probit }\end{array}$ & $\begin{array}{c}\text { (3) } \\
\text { Subjective Health } \\
\text { OLS }\end{array}$ & $\begin{array}{c}\text { (4) } \\
\text { Subjective Health } \\
\text { Ordered Probit }\end{array}$ \\
\hline \multicolumn{5}{|l|}{ main } \\
\hline male & $\begin{array}{l}0.129 * * * \\
\quad(9.84)\end{array}$ & $\begin{array}{l}0.118 * * * \\
\quad(9.71)\end{array}$ & $\begin{array}{l}0.101 * * * \\
(11.55)\end{array}$ & $\begin{array}{c}0.178 * * * \\
(11.68)\end{array}$ \\
\hline eta & $\begin{array}{c}-0.0838 * * * \\
(-9.76)\end{array}$ & $\begin{array}{c}-0.0841 * * * \\
(-10.30)\end{array}$ & $\begin{array}{c}-0.0341 * * * \\
(-10.69)\end{array}$ & $\begin{array}{c}-0.0662 * * * \\
(-11.48)\end{array}$ \\
\hline eta2 & $\begin{array}{l}0.00124 * * * \\
\quad(6.72)\end{array}$ & $\begin{array}{c}0.00128 * * * \\
(7.40)\end{array}$ & $\begin{array}{c}0.000464 * * * \\
(6.39)\end{array}$ & $\begin{array}{c}0.000936 * * * \\
(7.37)\end{array}$ \\
\hline eta3 & $\begin{array}{c}-0.00000699 * * * \\
(-5.95)\end{array}$ & $\begin{array}{c}-0.00000726^{* * * *} \\
(-6.61)\end{array}$ & $\begin{array}{c}-0.00000287 * * * \\
(-5.79)\end{array}$ & $\begin{array}{c}-0.00000560 * * * \\
(-6.64)\end{array}$ \\
\hline primary & $\begin{array}{c}-0.00553 \\
(-0.21)\end{array}$ & $\begin{array}{c}-0.00445 \\
(-0.20)\end{array}$ & $\begin{array}{c}0.0264^{*} \\
(1.80)\end{array}$ & $\begin{array}{c}0.0409 * \\
(1.68)\end{array}$ \\
\hline junior & $\begin{array}{c}0.0636^{* * *} \\
(2.33)\end{array}$ & $\begin{array}{c}0.0555^{* *} \\
(2.30)\end{array}$ & $\begin{array}{c}0.0680 * * * \\
(4.09)\end{array}$ & $\begin{array}{c}0.109 * * * \\
(3.89)\end{array}$ \\
\hline high & $\begin{array}{c}0.0772 * * * \\
(2.67)\end{array}$ & $\begin{array}{c}0.0657 * * \\
(2.53)\end{array}$ & $\begin{array}{c}0.142 * * * \\
(7.83)\end{array}$ & $\begin{array}{c}0.233 * * * \\
(7.76)\end{array}$ \\
\hline college & $\begin{array}{c}0.0155 \\
(0.38)\end{array}$ & $\begin{array}{c}0.00984 \\
(0.26)\end{array}$ & $\begin{array}{c}0.209 * * * \\
(8.91)\end{array}$ & $\begin{array}{c}0.349 * * * \\
(8.76)\end{array}$ \\
\hline Optimum circ. & $\begin{array}{c}0.521 * * * \\
(14.27)\end{array}$ & $\begin{array}{c}0.472 * * * \\
(13.70)\end{array}$ & $\begin{array}{c}0.284 * * * \\
(11.53)\end{array}$ & $\begin{array}{c}0.497 * * * \\
(11.62)\end{array}$ \\
\hline fairinc & $\begin{array}{c}0.398 * * * \\
(15.13)\end{array}$ & $\begin{array}{c}0.354 * * * \\
(14.50)\end{array}$ & $\begin{array}{l}0.155^{* * *} * \\
(8.31)\end{array}$ & $\begin{array}{l}0.257 * * * \\
(8.29)\end{array}$ \\
\hline badinc & $\begin{array}{c}0.132 * * * \\
(4.96)\end{array}$ & $\begin{array}{c}0.118 * * * \\
(4.83)\end{array}$ & $\begin{array}{c}0.0598 * * * \\
(3.33)\end{array}$ & $\begin{array}{c}0.0942 * * * \\
(3.15)\end{array}$ \\
\hline employed & $\begin{array}{c}0.122 * * * \\
(4.11)\end{array}$ & $\begin{array}{c}0.109 * * * \\
(4.00)\end{array}$ & $\begin{array}{c}0.0469 * * * \\
(3.15)\end{array}$ & $\begin{array}{c}0.0771 * * * \\
(2.89)\end{array}$ \\
\hline retired & $\begin{array}{c}0.142 * * * \\
(3.02)\end{array}$ & $\begin{array}{c}0.126 * * * \\
(2.99)\end{array}$ & $\begin{array}{c}0.0320 \\
(1.46)\end{array}$ & $\begin{array}{c}0.0473 \\
(1.27)\end{array}$ \\
\hline other_occup & $\begin{array}{c}-0.0115 \\
(-0.21)\end{array}$ & $\begin{array}{c}-0.00822 \\
(-0.17)\end{array}$ & $\begin{array}{c}-0.0344 \\
(-1.06)\end{array}$ & $\begin{array}{c}-0.0534 \\
(-1.02)\end{array}$ \\
\hline unable & $\begin{array}{c}-0.600 * * * \\
(-8.66)\end{array}$ & $\begin{array}{c}-0.562 * * * \\
(-8.48)\end{array}$ & $\begin{array}{c}-0.571^{* * *} * \\
(-11.08)\end{array}$ & $\begin{array}{c}-0.806 * * * \\
(-10.10)\end{array}$ \\
\hline housekeeper & $\begin{array}{c}0.141 * * * \\
(3.94)\end{array}$ & $\begin{array}{c}0.130 * * * \\
(3.96)\end{array}$ & $\begin{array}{c}0.0751 * * * \\
(4.09)\end{array}$ & $\begin{array}{c}0.127 * * * \\
(4.03)\end{array}$ \\
\hline sick & $\begin{array}{c}-0.288 * * * \\
(-9.05)\end{array}$ & $\begin{array}{c}-0.284 * * * \\
(-9.81)\end{array}$ & $\begin{array}{c}-0.347 * * * \\
(-17.50)\end{array}$ & $\begin{array}{c}-0.637 * * * \\
(-19.34)\end{array}$ \\
\hline rural & $\begin{array}{c}0.00867 \\
(0.23)\end{array}$ & $\begin{array}{c}-0.00230 \\
(-0.07)\end{array}$ & $\begin{array}{c}0.0382 * * \\
(1.99)\end{array}$ & $\begin{array}{c}0.0637 * \\
(1.96)\end{array}$ \\
\hline Nohealthrel & $\begin{array}{c}-0.260 * * * \\
(-17.31)\end{array}$ & $\begin{array}{c}-0.235 * * * \\
(-17.37)\end{array}$ & $\begin{array}{c}-0.0875 * * * \\
(-10.45)\end{array}$ & $\begin{array}{c}-0.149 * * * \\
(-10.43)\end{array}$ \\
\hline married & $\begin{array}{c}0.124 * * * \\
(5.73)\end{array}$ & $\begin{array}{c}0.113 * * * \\
(5.85)\end{array}$ & $\begin{array}{c}-0.0711 * * * \\
(-6.81)\end{array}$ & $\begin{array}{c}-0.118 * * * \\
(-6.53)\end{array}$ \\
\hline separ & $\begin{array}{c}-0.0881^{*} \\
(-1.89)\end{array}$ & $\begin{array}{c}-0.0778^{*} \\
(-1.88)\end{array}$ & $\begin{array}{c}-0.0414 * * \\
(-1.99)\end{array}$ & $\begin{array}{c}-0.0689 * * \\
(-1.98)\end{array}$ \\
\hline divorced & $\begin{array}{c}-0.118 * * \\
(-2.00)\end{array}$ & $\begin{array}{c}-0.0942^{*} \\
(-1.79)\end{array}$ & $\begin{array}{c}-0.0226 \\
(-0.64)\end{array}$ & $\begin{array}{c}-0.0316 \\
(-0.54)\end{array}$ \\
\hline widow & $\begin{array}{c}-0.127 * * * \\
(-4.01)\end{array}$ & $\begin{array}{c}-0.104 * * * \\
(-3.68)\end{array}$ & $\begin{array}{c}-0.0667 * * * \\
(-4.05)\end{array}$ & $\begin{array}{c}-0.105 * * * \\
(-3.92)\end{array}$ \\
\hline houseproblems & $\begin{array}{c}-0.205 * * * \\
(-7.46)\end{array}$ & $\begin{array}{c}-0.182 * * * \\
(-7.42)\end{array}$ & $\begin{array}{c}-0.0521 * * * \\
(-3.69)\end{array}$ & $\begin{array}{c}-0.0878 * * * \\
(-3.73)\end{array}$ \\
\hline Norel & $\begin{array}{c}-0.0754 * * * \\
(-4.53)\end{array}$ & $\begin{array}{c}-0.0661 * * * \\
(-4.30)\end{array}$ & $\begin{array}{c}-0.0212 * * \\
(-2.23)\end{array}$ & $\begin{array}{c}-0.0380^{* * *} \\
(-2.33)\end{array}$ \\
\hline nofriend & $\begin{array}{c}-0.0615 * * * \\
(-3.92)\end{array}$ & $\begin{array}{c}-0.0509 * * * \\
(-3.55)\end{array}$ & $\begin{array}{c}-0.0367 * * * \\
(-4.60)\end{array}$ & $\begin{array}{c}-0.0617 * * * \\
(-4.53)\end{array}$ \\
\hline
\end{tabular}


Social Comparison And Subjective Well-being

\begin{tabular}{|c|c|c|c|c|}
\hline noneigh & $\begin{array}{c}-0.00431 \\
(-0.32)\end{array}$ & $\begin{array}{c}-0.00764 \\
(-0.62)\end{array}$ & $\begin{array}{c}-0.00117 \\
(-0.15)\end{array}$ & $\begin{array}{c}-0.00149 \\
(-0.11)\end{array}$ \\
\hline novoulun & $\begin{array}{c}-0.0543 * * * \\
(-2.60)\end{array}$ & $\begin{array}{c}-0.0508 * * * \\
(-2.60)\end{array}$ & $\begin{array}{c}0.0267^{* *} \\
(2.54)\end{array}$ & $\begin{array}{c}0.0467^{* *} \\
(2.58)\end{array}$ \\
\hline meanrich & $\begin{array}{l}-0.219 \\
(-0.84)\end{array}$ & $\begin{array}{l}-0.166 \\
(-0.71)\end{array}$ & $\begin{array}{c}-0.474 * * * \\
(-3.77)\end{array}$ & $\begin{array}{c}-0.790 * * * \\
(-3.69)\end{array}$ \\
\hline meansick & $\begin{array}{l}0.125 \\
(1.15)\end{array}$ & $\begin{array}{c}0.0801 \\
(0.80)\end{array}$ & $\begin{array}{c}-0.364 * * * \\
(-6.08)\end{array}$ & $\begin{array}{c}-0.680 * * * \\
(-6.59)\end{array}$ \\
\hline sick_meansick & $\begin{array}{c}-0.260 * * * \\
(-3.90)\end{array}$ & $\begin{array}{c}-0.182 * * * \\
(-3.02)\end{array}$ & $\begin{array}{c}-0.280 * * * \\
(-7.35)\end{array}$ & $\begin{array}{c}-0.353 * * * \\
(-5.57)\end{array}$ \\
\hline visit & & & $\begin{array}{c}-0.217 * * * \\
(-21.05)\end{array}$ & $\begin{array}{c}-0.356 * * * \\
(-21.66)\end{array}$ \\
\hline Hosp. days & & & $\begin{array}{c}-0.0294 * * * \\
(-12.51)\end{array}$ & $\begin{array}{c}-0.0468 * * * \\
(-10.99)\end{array}$ \\
\hline _cons & $\begin{array}{c}5.708 * * * \\
(46.56)\end{array}$ & & $\begin{array}{c}4.869 * * * \\
(99.15)\end{array}$ & \\
\hline cut1 & & & & \\
\hline _cons & & $\begin{array}{c}-3.911 * * * \\
(-32.93)\end{array}$ & & $\begin{array}{c}-5.293 * * * \\
(-55.97) \\
\end{array}$ \\
\hline cut2 & & & & \\
\hline _cons & & $\begin{array}{c}-3.009 * * * \\
(-25.43) \\
\end{array}$ & & $\begin{array}{c}-4.213 * * * \\
(-44.48) \\
\end{array}$ \\
\hline cut3 & & & & \\
\hline _cons & & $\begin{array}{c}-1.925^{* * *} \\
(-16.37)\end{array}$ & & $\begin{array}{c}-2.434 * * * \\
(-25.97)\end{array}$ \\
\hline cut 4 & & & & \\
\hline _cons & & $\begin{array}{c}-1.500 * * * \\
(-12.77) \\
\end{array}$ & & $\begin{array}{c}-0.890 * * * \\
(-9.58) \\
\end{array}$ \\
\hline cut5 & & & & \\
\hline _cons & & $\begin{array}{c}-0.349 * * * \\
(-2.95) \\
\end{array}$ & & \\
\hline $\mathrm{N}$ & 42223 & 42223 & 44470 & 44470 \\
\hline Adjusted $\mathrm{R}^{2}$ & 0.201 & & 0.484 & \\
\hline Log-likelihood & -65903.7 & -61285.3 & -44340.1 & -43028.6 \\
\hline Chi-square stat. & & 7524.7 & & 19801.2 \\
\hline
\end{tabular}

$t$ statistics in parentheses. Standard errors are clustered on 464 reference groups

$* p<.10, * * p<.05, * * * p<0.01$ 